\title{
Canadian consensus guidelines for the management of testicular germ cell cancer
}

\author{
Lori Wood, MD, ${ }^{*}$ Christian Kollmannsberger, MD, FRCSC, ${ }_{;}^{+}$Michael Jewett, MD, FRCSC,; Peter Chung, MD; ${ }^{-\xi}$

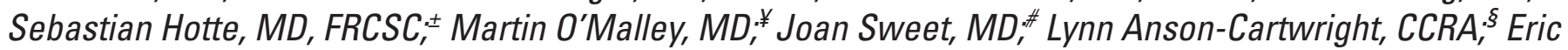

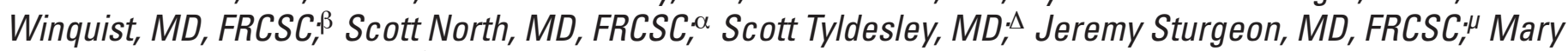 \\ Gospodarowicz, MD, FRCSC,; Roanne Segal, MD; ; Tina Cheng, MD; ; Peter Venner, MD, FRCSC, ${ }_{r}^{* \alpha}$ Malcolm

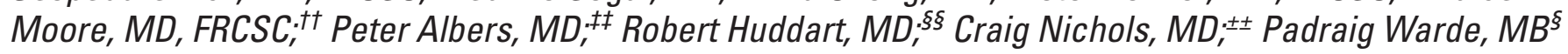

Can Urol Assoc J 2010;4(2):E19-E38

$\mathrm{T}$ esticular tumours are uncommon but constitute an important group of malignancies in young men. Worldwide, it is estimated that there were more than 48500 new cases and 8900 deaths from the disease in $2002 .^{1}$ The vast majority are primary germ cell tumours (GCTs) and the incidence has doubled in the past 30 years (with most of the increase in seminomas). ${ }^{2}$ While most patients present with early-stage and highly curable disease, the continued rise in the incidence of these tumours presents a major challenge.

Germ cell testicular tumours are the most common solid malignancies in males between the ages of 20 and 35; it is estimated that in 2008 there will be 900 new cases and 30 deaths from testicular cancer in Canada. ${ }^{3}$

Germ cell cancer is a rare disease that requires expert treatment. Clear evidence has emerged that patients with germ cell cancer benefit from treatment in centres with special experience in the field. ${ }^{4}$ However, it is also of considerable importance that clear, comprehensive and up-todate consensus guidelines are available which represent the current "state of the art" in diagnosis and management of germ cell cancer. The European Germ Cell Cancer Consensus Group published guidelines in 2004 (updated in 2008) and these reflect the "European" approach to management of patients with GCTs. ${ }^{5-7}$ In October 2007, the 1st Canadian Germ Cell Cancer Consensus Conference was held in Toronto with support from the Canadian Partnership against Cancer (CPAC), the Canadian Institute of Health Research, multiple provincial cancer agencies, the Dell'Elce Testicular Cancer Research Fund from the Princess Margaret Foundation and industry sponsors. The initiative was endorsed by the Canadian Urological Association, the Canadian Association of Medical Oncologists and the Canadian Association of Radiation Oncologists. There were a total of 46 attendees from across Canada and international invitees (Dr. Peter Albers, Dr. Robert Huddart and Dr. Craig Nichols). The group reviewed and discussed the current literature and the Canadian experience with germ cell cancer. The group developed this Canadian Consensus Guideline to cover many aspects of the diagnosis and management of germ cell cancer.

\section{Diagnosis and staging}

\section{Clinical presentation of germ cell tumour}

Most patients present with a primary tumour in the testis. Delay in diagnosing germ cell cancer, which has been shown to affect outcome, may be caused either by patients who ignore symptoms for too long or by physicians who fail to make the correct diagnosis. ${ }^{8}$ In a minority of patients, the primary tumour manifestation is located extragonadally (i.e., in the retroperitoneum or in the mediastinum). ${ }^{5}$

\section{Consensus recommendations}

There are mandatory diagnostic and staging examinations (Table 1). These include scrotal examination, determination of the serum tumour markers alpha-fetoprotein (AFP), ß-human chorionic gonadotrophin (HCG) and lactate dehydrogenase $(\mathrm{LDH})$, scrotal ultrasound to image the testis, computed tomography (CT) scan of the thorax, abdomen and pelvis (chest $\mathrm{x}$-ray should be used instead of CT thorax in stage I seminoma). Bone scan and CT scan of the brain are indicated in patients with symptoms suggestive of central nervous system or bone involvement and in patients with poor prognosis disease. Other imaging procedures, such as magnetic resonance imaging (MRI) and positron emission tomography (PET), should not be routinely used. 
Wood et al.

\section{Table 1. Mandatory investigations}

Complete history and physical exam, including scrotal exam

Laboratory

- Alpha-fetoprotein, ß-human chorionic gonadotrophin

- Lactate dehydrogenase

Imaging*

- Scrotal Ultrasound

- CT abdomen and pelvis

- CT thorax (chest $\mathrm{x}$-ray if stage I seminoma)

$\mathrm{CT}=$ computed tomogramphy; ${ }^{*}=$ Bone scan and brain imaging only in patients with symptoms or poor prognosis metastatic disease.

Further investigations to determine their eventual place in this setting are required.

Tumour marker values should be available prior to surgery and should be repeated at intervals to measure the half-life kinetics (half-life AFP $<7$ days, B-HCG $<3$ days).

Radical orchiectomy should be performed through an inguinal incision and the testicle should be removed along with the spermatic cord to the level of the internal inguinal ring. In very rare cases where there is a possibility of a benign tumour, excisional biopsy with a frozen section should be performed prior to definitive orchiectomy to allow for the possibility of organ-sparing partial orchiectomy.

In patients with synchronous bilateral tumours, metachronous contralateral tumours or solitary testicles with normal preoperative testosterone levels, organ-preserving surgery may be an alternative procedure to orchiectomy in very select patients; this should be discussed with the patient. If this approach is considered, the patient should undergo surgery by a surgeon with experience in this procedure. If organ-preserving surgery is performed and intratubular germ cell neoplasia unclassified is found in the remaining testicular tissue, adjuvant radiotherapy is recommended but may be delayed in patients who wish to father children. A full discussion on semen cyropreservation and androgen replacement should take place.

In general, orchiectomy should be performed prior to any further treatment. In patients with life-threatening metastatic disease and an unequivocally elevated AFP and/or HCG, orchiectomy should not delay the start of chemotherapy and can be postponed until later in the treatment course.

The UICC (Union Internationale Contre le Cancer) TNM classification system should be used for staging purposes (Table 2a). ${ }^{9}$ Patients with metastatic disease are classified according to the classification system of the International Germ Cell Cancer Collaborative Group (IGCCCG). ${ }^{10,11}$ Using this system, patients are divided into "good," "intermediate" and "poor" prognosis groups (Table 2b).

The histopathological report should document the following points: localization and size of the tumour, multiplicity, tumour extension (rete testis, tunica albuginea, tunica vaginalis, epididymis, spermatic cord, scrotum), PT category according to the UICC classification, histological type, the presence or absence of tubular intra-epithelial neoplasia, as well as the presence or absence of vascular invasion of blood or lymphatic vessels. In tumours with multiple tumour types, each individual component and its estimated relative proportion should be reported. Because of the clinical importance of all histological specimens, it is highly recommended that they are assessed by a pathologist experienced in testis cancer pathology. ${ }^{12}$

\section{Management of stage I and II testicular seminoma}

\section{Stage I seminoma}

Although radiotherapy has been the standard treatment of clinical stage I seminoma patients for the past 65 years, there is growing recognition that adjuvant radiotherapy is associated with an increased risk of late side effects, including second non-testicular malignancies and cardiovascular disease. Concerns regarding late toxicity of radiotherapy, success of surveillance in stage I nonseminomatous GCTs and improvements in diagnostic imaging have led to an assessment of close surveillance after orchiectomy for stage I seminoma, with treatment reserved for those who relapse.

\section{Surveillance}

Numerous prospective non-randomized studies of surveillance have been performed (Table 3). ${ }^{13-20}$ The data in these series are now mature and relapse rates have consistently been reported to be about $15 \%$ in unselected patients with stage I disease. The predominant site of relapse in all studies was in the paraaortic lymph nodes; 41 of 49 (82\%) of relapses in the Danish Testicular Cancer Study Group (DATECA) study and 57 of 64 (85\%) in the Princess Margaret Hospital (PMH) series. ${ }^{18,19}$ The median time to relapse ranged from 12 to 18 months, but late relapses ( $>4$ years) have been reported in some series. Disease-specific survival is $99 \%$ and thus comparable to other options.

Tumour size and rete testis invasion have been shown in a pooled analysis of 638 cases from 4 centres to predict for relapse. ${ }^{21}$ Using this prognostic model, a risk-adapted approach to management has been reported by the Spanish Germ Cell Cancer Cooperative Study Group with surveillance reserved for low-risk patients and adjuvant therapy for patients with 1 or 2 adverse prognostic factors. ${ }^{22}$ This study confirmed that low-risk patients (no adverse factors) had a small risk of relapse. However, a risk-adapted approach to management cannot be recommended at the present time because the prognostic model suffers from two major problems. Firstly, the model has not been validated in an independent data set; secondly, the model does not have 
Table 2a. Staging of testis tumours: UICC/American Joint Committee on Cancer

\begin{tabular}{|c|c|c|}
\hline TNM staging & Unit & Value \\
\hline \multirow[t]{7}{*}{$\begin{array}{l}\text { Primary } \\
\text { tumour* }\end{array}$} & pTX & $\begin{array}{l}\text { Primary tumour cannot be assessed. } \\
\text { (If no radical orchidectomy has been } \\
\text { performed, Tx is used) }\end{array}$ \\
\hline & pT0 & $\begin{array}{l}\text { No evidence of primary tumour } \\
\text { (e.g., histologic scar in testis) }\end{array}$ \\
\hline & pTis & $\begin{array}{l}\text { Intratubular germ cell neoplasia } \\
\text { (carcinoma in situ) }\end{array}$ \\
\hline & pT1 & $\begin{array}{l}\text { Tumour limited to the testis and } \\
\text { epididymis without vascular/ } \\
\text { lymphatic invasion. Tumour may } \\
\text { invade into the tunica albuginea } \\
\text { but not the tunica vaginalis. }\end{array}$ \\
\hline & pT2 & $\begin{array}{l}\text { Tumour limited to the testis and } \\
\text { epididymis with vascular/lymphatic } \\
\text { invasion, or tumour extending } \\
\text { through the tunica albuginea with } \\
\text { involvement of the tunica vaginalis }\end{array}$ \\
\hline & pT3 & $\begin{array}{l}\text { Tumour invades the spermatic } \\
\text { cord with or without } \\
\text { vascular/lymphatic invasion }\end{array}$ \\
\hline & pT4 & $\begin{array}{l}\text { Tumour invades the scrotum with or } \\
\text { without vascular/lymphatic invasion }\end{array}$ \\
\hline $\begin{array}{l}\text { Regional } \\
\text { lymph nodes }\end{array}$ & $N X$ & $\begin{array}{l}\text { Regional lymph nodes cannot be } \\
\text { assessed }\end{array}$ \\
\hline
\end{tabular}

(N) clinical

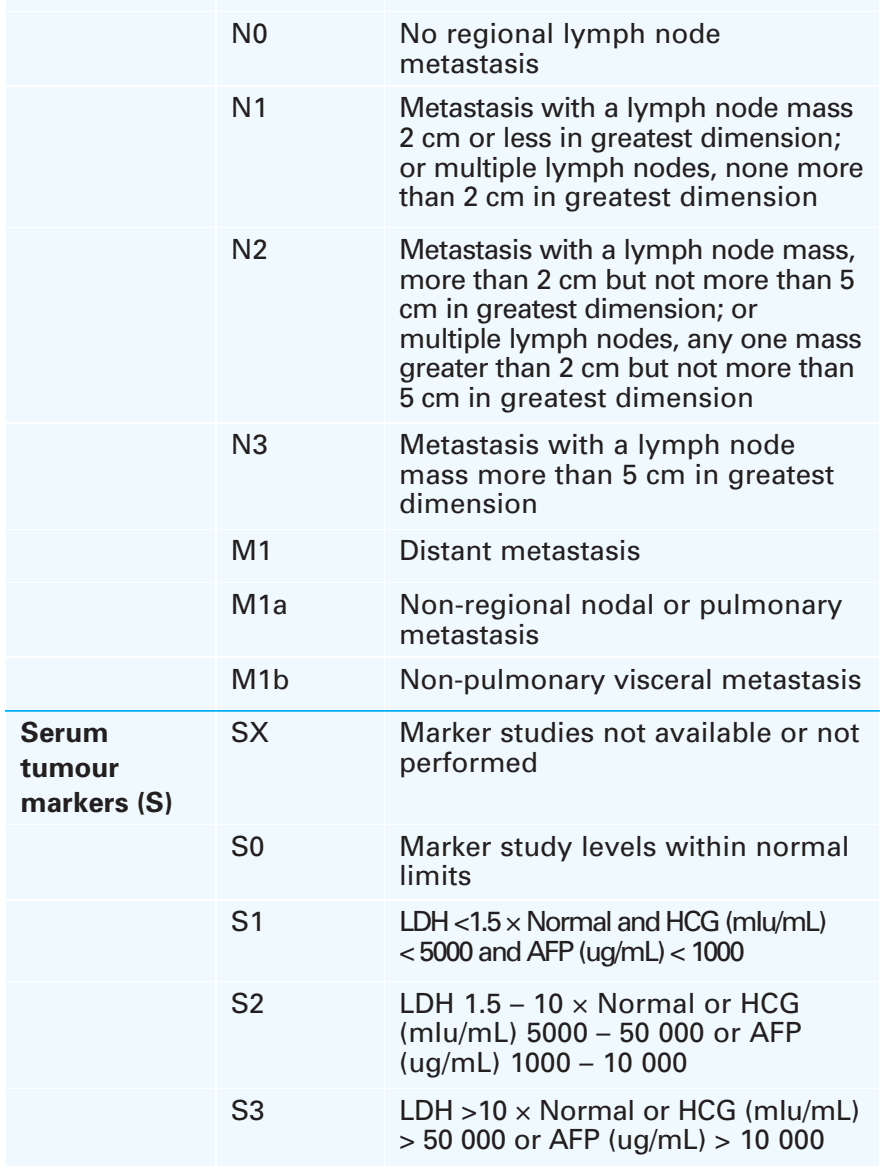

\begin{tabular}{|c|c|c|c|c|}
\hline \multicolumn{5}{|c|}{ Stage grouping } \\
\hline Stage & Tumour & Node & Metastasis & Serum factor \\
\hline Stage 0 & pTis & No & Mo & So \\
\hline Stage I & pT1-4 & No & Mo & SX \\
\hline Stage IA & pT1 & No & Mo & So \\
\hline \multirow[t]{3}{*}{ Stage 1B } & pT2 & No & Mo & So \\
\hline & pT3 & No & Mo & So \\
\hline & pT4 & No & Mo & So \\
\hline Stage IS & Any $T$ & No & Mo & S1-3 \\
\hline Stage II & Any $T$ & N1-3 & Mo & sX \\
\hline \multirow[t]{2}{*}{ Stage IIA } & Any $\mathrm{T}$ & N1 & Mo & So \\
\hline & Any $T$ & N1 & Mo & S1 \\
\hline \multirow[t]{2}{*}{ Stage IIB } & Any $T$ & N2 & Mo & So \\
\hline & Any $\mathrm{T}$ & N2 & Mo & S1 \\
\hline \multirow[t]{2}{*}{ Stage IIC } & Any $T$ & N3 & Mo & So \\
\hline & Any $T$ & N3 & Mo & S1 \\
\hline Stage III & Any $T$ & Any $N$ & M1 & sX \\
\hline \multirow[t]{2}{*}{ Stage IIIA } & Any $T$ & Any N & M1a & So \\
\hline & Any $\mathrm{T}$ & Any N & M1a & S1 \\
\hline \multirow[t]{2}{*}{ Stage IIIB } & Any $T$ & N1-3 & Mo & $\mathrm{S} 2$ \\
\hline & Any $\mathrm{T}$ & Any $N$ & M1a & S2 \\
\hline \multirow[t]{3}{*}{ Stage IIIC } & Any $T$ & N1-3 & Mo & S3 \\
\hline & Any $\mathrm{T}$ & Any $N$ & M1a & S3 \\
\hline & Any $\mathrm{T}$ & Any N & M1B & Any $S$ \\
\hline
\end{tabular}

*The extent of primary tumour is classified after radical orchidectomy. LDH = lactate dehydrogenase; $\mathrm{HCG}$ = human chorionic gonadotrophin; AFP = alpha-fetoprotein. Adapted from Sobin LH, Wittekind C (eds). UICC TNM classification of malignant tumours. 6 th ed. New York: John Wiley \& Sons, 2002.

sufficient discrimination to be clinically useful. Even patients in the high-risk group have a greater than $65 \%$ chance of being relapse-free on surveillance.

At relapse, most patients can be successfully treated with retroperitoneal radiotherapy alone. One concern regarding the routine use of surveillance was the potential for the increased use of chemotherapy. However, data from $\mathrm{PMH}$ indicates that the 10-year actuarial risk of requiring chemotherapy at any time in the management of patients was $4.6 \%$ in patients managed by surveillance and $3.9 \%$ in those managed by adjuvant radiotherapy; this data suggest that there is no significant increase of the use of chemotherapy in patients followed on surveillance. ${ }^{19}$

An optimal follow-up strategy for patients on surveillance has not yet been determined. The National Cancer Research Institute in the United Kingdom has opened a randomized trial (TRISST) to address this issue. Patients with stage I seminoma will be randomized to either $\mathrm{CT}$ or 
Wood et al.

\begin{tabular}{|c|c|c|}
\hline Histology & $\begin{array}{l}\text { Prognostic } \\
\text { category }\end{array}$ & Clinical factors \\
\hline NSGCT & Good & $\begin{array}{l}\text { Testes/retroperitoneal primary and } \\
\text { no non-pulmonary visceral } \\
\text { metastases and good markers: } \\
\text { AFP }<1000 \mathrm{ng} / \mathrm{ml} \text { and } \\
\text { HCG }<5000 \mathrm{IU} / \mathrm{l} \text { and } \\
\text { LDH }<1.5 \times \text { ULN* }\end{array}$ \\
\hline
\end{tabular}

Intermediate Testes/retroperitoneal primary and no non-pulmonary visceral metastases and intermediate markers: AFP $\geq 1000 \mathrm{ng} / \mathrm{mL}$ and $\leq 10,000 \mathrm{ng} / \mathrm{mL}$ or $\mathrm{HCG} \geq 5000 \mathrm{IU} / \mathrm{l}$ and $\leq 50,000 \mathrm{ng} / \mathrm{mL}$ or $\mathrm{LDH} \geq 1.5 \times \mathrm{ULN}$ and $\leq 10 \times \mathrm{ULN}$

\begin{tabular}{|c|c|c|}
\hline & Poor & $\begin{array}{l}\text { Mediastinal primary or non- } \\
\text { pulmonary visceral metastases or } \\
\text { poor markers with any of: } \\
\text { AFP }>10,000 \mathrm{ng} / \mathrm{mL} \text { or } \\
\text { HCG }>50,000 \mathrm{IU} / \mathrm{l} \text { or } \\
\mathrm{LDH}>10 \times \mathrm{ULN}\end{array}$ \\
\hline \multirow[t]{2}{*}{ Seminoma } & Good & $\begin{array}{l}\text { Any primary site and } \\
\text { no non-pulmonary visceral } \\
\text { metastases and } \\
\text { normal AFP, any HCG, any LDH }\end{array}$ \\
\hline & Intermediate & $\begin{array}{l}\text { Any primary site and } \\
\text { non-pulmonary visceral metastases } \\
\text { and normal AFP, any HCG, any LDH }\end{array}$ \\
\hline
\end{tabular}

NSGCT = nonseminoma germ cell tumour; AFP = alpha-fetoprotein; $\mathrm{HCG}=$ human chorionic gonadotrophin; LDH = lactate dehydrogenase; ULN = upper limit of normal.

MRI in follow-up with a second randomization to either 3 scans or 7 scans in total. This study has been endorsed by the National Cancer Institute of Canada-Clinical Trials Group (NCIC-CTG) genitourinary Group.

\section{Adjuvant radiotherapy}

Adjuvant retroperitoneal radiotherapy has been the standard treatment of stage I seminoma for more than 60 years. The overall survival rate in most series in the modern era ranges between 92 and 99\% at 10 years, with few if any deaths from seminoma. In large single or multi-institutional series, the relapse rate has varied from $0.5 \%$ to $5 \%$ (Table 4). ${ }^{19,23-27}$ The most common sites of relapse following adjuvant radiotherapy are the mediastinum, lungs and the left supraclavicular fossa. A small proportion of patients, usually with predisposing factors, relapse in the inguinal nodes. Chemotherapy is the treatment of choice for supradiaphragmatic relapse and gives close to a 100\% cure rate. Inguinal relapse can often be treated successfully with radiotherapy to the involved area. ${ }^{28}$

Most relapses occur within 2 years of radiotherapy. In the PMH series, 283 patients treated between 1981 and
2004 had a median time to relapse of 18 months, with the latest relapse occurring at 6 years. Follow-up efforts should therefore concentrate on the first 2 years after radiotherapy.

The traditional management of stage I seminoma patients after orchiectomy has consisted of radiotherapy to the paraaortic and pelvic (retroperitoneal) lymph nodes. The low incidence of pelvic lymph node involvement in stage I seminoma led to the investigation of adjuvant radiotherapy directed to the paraaortic lymph nodes alone. The advantages of such an approach include decreased scatter to the remaining testicle and a reduction in the integral radiation dose that the patient receives, presumably decreasing the risk of second malignancy. The Medical Research Council Testicular Study Group randomized 478 patients to traditional paraaortic and pelvic radiation or paraaortic irradiation alone. ${ }^{29}$ Patients treated with paraaortic radiotherapy alone had a $4 \%$ relapse rate compared to a $3.4 \%$ relapse rate in patients treated to the paraaortic and pelvic lymph nodes. All patients who received paraaortic and pelvic radiotherapy relapsed in supra-diaphragmatic sites, but $1.6 \%$ of patients treated to the paraaortic lymph nodes alone group failed with disease in the pelvis. This trial demonstrated that treating the paraaortic nodes alone gives excellent results, but when used a small risk of pelvic failure remains. Therefore, if this treatment approach is adopted, regular imaging with CT of the pelvic lymph nodes must be performed to ensure that if pelvic relapse occurs, it is detected at an early stage. Data from the Christie Hospital in Manchester, United Kingdom, where no routine evaluation of the pelvis is carried out after paraaortic radiation alone, has shown that the median size of the pelvic lymph nodes at time of detection of relapse is $5 \mathrm{~cm}$ (range 2.5 to $9 \mathrm{~cm}$ ). ${ }^{30}$ The advantage of paraaortic radiotherapy alone is therefore not clear, particularly in comparison to surveillance.

Data from the MD Anderson and the Royal Marsden hospitals suggest that long-term survivors of testicular seminoma treated postorchiectomy with radiotherapy are at significant excess risk of death as a result of cardiac disease. ${ }^{31,32}$ In the MD Anderson series of 453 patients treated between 1951 and 1999, the standardized cardiac mortality ratio for patients greater than 15 years after radiotherapy (infradiaphragmatic radiotherapy, no mediastinal radiotherapy) was $1.80(95 \% \mathrm{Cl} 1.01-2.98) .{ }^{32}$ Huddart and colleagues reported a similar increase in cardiac events in a cohort of 992 patients treated at the Royal Marsden Hospital with a risk-ratio of $2.4(95 \% \mathrm{Cl} 1.04-5.45)$ in those treated with infra-diaphragmatic radiotherapy as compared to those managed by surveillance. ${ }^{31}$

An increased risk of second cancers after radiation therapy for stage I seminoma has been documented in a number of studies, and since this increased risk is expressed more than 10 to 15 years following radiation therapy, it is often not apparent in series with shorter follow-up. ${ }^{33,34}$ The 
Table 3. Summary of surveillance studies in stage I seminoma

\begin{tabular}{|c|c|c|c|c|c|c|}
\hline Author & Year & $\begin{array}{c}\text { Median } \\
\text { follow-up (mo) }\end{array}$ & No. patients & $\begin{array}{l}\text { No. patients } \\
\text { relapse }\end{array}$ & Relapse, \% & $\begin{array}{c}\text { Cause-specific } \\
\text { survival, \% }\end{array}$ \\
\hline Daugaard $^{13}$ & 2003 & 60 & 394 & 69 & 17.5 & 100 \\
\hline Germa Lluch ${ }^{14}$ & 2002 & 33 & 233 & 38 & 16 & 100 \\
\hline Horwich $^{15}$ & 1992 & 62 & 103 & 17 & 16.5 & 100 \\
\hline Oliver ${ }^{16}$ & 2001 & 98 & 110 & 21 & 19 & 100 \\
\hline Ramakrishnan ${ }^{17}$ & 1992 & 44 & 72 & 13 & 18 & 100 \\
\hline Von der Maase ${ }^{18}$ & 1993 & 48 & 261 & 49 & 18.8 & 98.9 \\
\hline Warde ${ }^{19}$ & 2005 & 98 & 421 & 64 & 15.2 & 99.7 \\
\hline Tyldesley ${ }^{20}$ & 2006 & 33 & 93 & 16 & 17.2 & 97.8 \\
\hline
\end{tabular}

largest study of second cancers in long-term survivors of testicular cancer was conducted by Travis and colleagues at the National Cancer Institute Cancer Epidemiology Division. ${ }^{35}$ This report combined 14 population-based registries including 10534 patients with seminoma (all stages) treated with radiotherapy. Compared with matched cohorts from corresponding registries, the overall relative risk of a second non-testicular malignancy was 2.0 (95\% Cl 1.8-2.2). For a 35-year-old patient with seminoma, the cumulative $40-$ year risk of a second malignancy was $36 \%$, compared with $23 \%$ in the normal population. These results were confirmed in a Dutch population-based study of more than 2700 long-term GCT survivors in which the second malignancy risk with subdiaphragmatic radiation therapy was 2.6-fold increased as compared to surgery alone. ${ }^{36}$ The increased risk associated with radiation therapy was similar to the increased cancer risk seen with smoking.

\section{Adjuvant chemotherapy}

Adjuvant chemotherapy using 1 to 2 cycles of carboplatin has recently being investigated as an alternative manage-

\begin{tabular}{|c|c|c|c|c|}
\hline Author & $\begin{array}{l}\text { Years of } \\
\text { study }\end{array}$ & No. patients & Relapse, \% & $\begin{array}{c}\text { Cause- } \\
\text { specific } \\
\text { survival, \% }\end{array}$ \\
\hline Bayens $^{23}$ & 1975-1985 & 132 & 4.5 & $99 \%$ \\
\hline Coleman ${ }^{24}$ & 1980-1995 & 144 & 4.2 & $100 \%$ \\
\hline Fossa $^{25}$ & 1989-1993 & 478 & 3.8 & $100 \%$ \\
\hline Jones $^{26}$ & 1995-1998 & 625 & 3.5 & $9.6 \%$ \\
\hline Santoni ${ }^{27}$ & 1970-1999 & 487 & 4.3 & $99.4 \%$ \\
\hline Warde ${ }^{19}$ & $1981-2002$ & 283 & 5 & $100 \%$ \\
\hline
\end{tabular}

ment strategy. The Medical Research Council in the United Kingdom has conducted a randomized phase III study of 1447 patients comparing adjuvant radiotherapy and a single course of carboplatin. ${ }^{37}$ The relapse rate in both arms of the study was similar at 3 years $(3.4 \%$ radiotherapy vs. $4.6 \%$ carboplatin) with most of the recurrences in the carboplatin arm occurring in the retroperitoneal lymph nodes. One possible benefit of adjuvant carboplatin noted in this setting was a reduction in the incidence of second primary testicular GCTs. Data from other single institution series indicate that if adjuvant carboplatin is given in this setting, 2 courses of treatment are likely necessary. ${ }^{22,38}$ Even with 2 cycles of carboplatin, a small but significant percentage of patients recur in the retroperitoneum and the usefulness of this approach is questionable. The relapse pattern after adjuvant single agent carboplatin mandates that continued surveillance of the retroperitoneal lymph nodes is required (similar to surveillance), and the reduction in relapse rates is only from $15 \%$ with surveillance to $5 \%$ in those given adjuvant chemotherapy. Eighty-five percent of patients receive unnecessary treatment and the long-term toxicity and long-term control rates with this strategy are unknown.

\section{Consensus recommendations}

Patients should be informed of all treatment options, including the potential benefits and side effects of each treatment.

In a patient willing and able to adhere to a surveillance program, this approach should be considered as the management option of choice (Fig 1).

A risk-adapted approach with surveillance for low-risk patients and treatment for those at higher risk of relapse cannot be recommended at the present time; the prognostic model on which this approach is based has not been validated and has poor discriminative ability. 


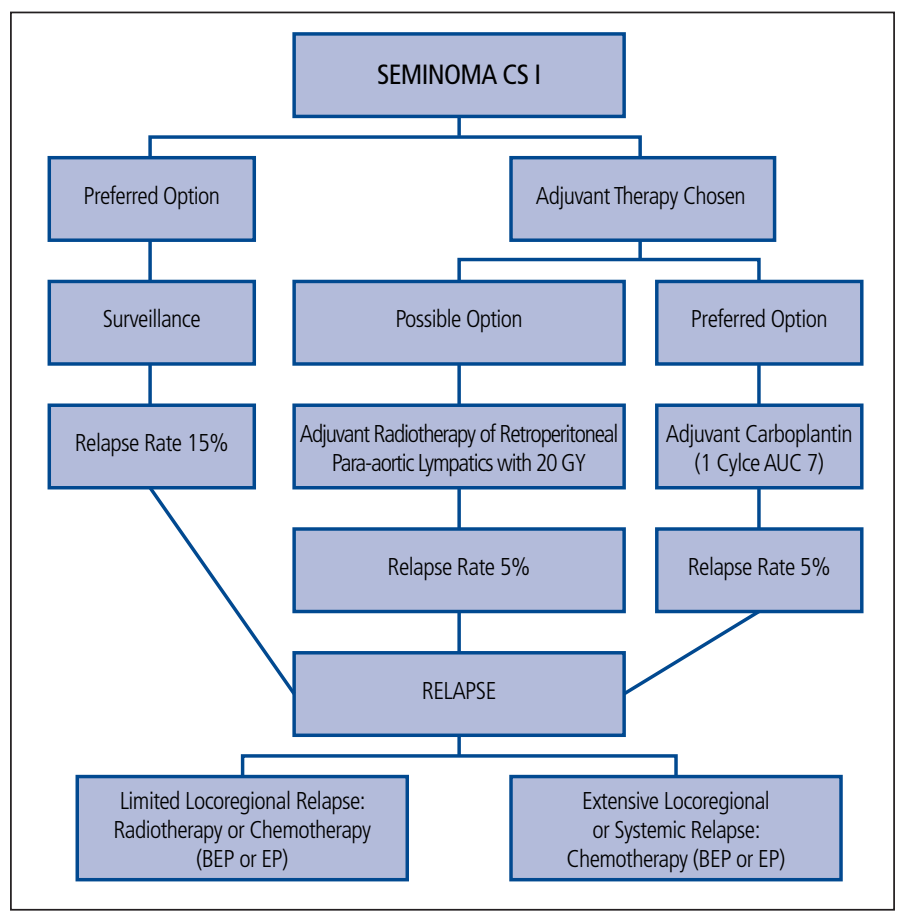

Fig 1. Schema for the management of stage I seminoma.

When adjuvant therapy is chosen:

1. Radiation therapy remains the preferred option for patients.

2. Adjuvant chemotherapy using single-agent carboplatin is an option but requires continuing CT imaging.

\section{Stage II seminoma}

In stage IIA seminoma, radiation therapy is the preferred treatment over chemotherapy if there are no contraindications. Radiation therapy is given to the paraaortic and ipsilateral pelvic nodes and with doses in the range of 30 Gy to $35 \mathrm{~Gy}$, the 5-year relapse free-rate is in excess of $90 \%$ in most modern series. In stage IIB disease, depending on the bulk of disease and location of lymph nodes, radiation therapy or chemotherapy (etoposide and cisplatin [EP] $\times 4$ cycles or bleomycin, etoposide and cisplatin [BEP] $\times 3$ cycles) can be used. The relapse-free rate with radiation therapy is close to $90 \%$ and most relapses are cured with salvage chemotherapy. With primary chemotherapy, there are very few relapses and the overall disease-specific survival is close to $100 \%$ whichever management approach is adopted.

A CT scan of the abdomen and pelvis should be performed about 3 months after treatment to monitor response to therapy. Repeated imaging should be performed at 3 to 6 monthly intervals until there is complete regression of disease.

Stage IIC disease should be managed by primary chemotherapy (same as good-risk metastatic nonseminomas) as the relapse rate with radiation therapy approaches
$50 \%$ in most series, and not all patients can be salvaged with chemotherapy.

\section{Consensus recommendations}

In stage IIA disease, radiation therapy should be considered standard treatment if there are no contraindications. Otherwise, chemotherapy is an option.

In stage IIB disease, chemotherapy or RT are reasonable treatment approaches.

In stage IIC disease, chemotherapy should be considered the standard treatment approach.

\section{Management of stage I testicular nonseminoma}

Testicular cancer is classified as nonseminoma if, histologically, the tumour contains any component of embryonal carcinoma, yolk sac tumour, choriocarcinoma, or immature teratoma. Patients with histologically pure seminoma but elevated serum AFP or markedly elevated HCG levels may also be considered to have nonseminoma. Patients are considered to have clinical stage I disease after radical orchiectomy when imaging investigations (including CT abdomen and pelvis, chest) and serum tumour markers (i.e., AFP, HCG, LDH) are normal. Pathological stage I disease is similarly defined except that the men have also had a pathologically negative retroperitoneal lymphadenectomy (RPLND). If lymph node metastases are present and completely excised, the patient is considered to have pathological stage II (PS II) disease. While most patients with clinical stage I nonseminoma germ cell tumour (NSGCT) are cured with orchiectomy, about $20 \%$ to $30 \%$ will experience recurrence and require additional treatment for cure.

Historically, RPLND has been used for both staging and therapeutic purposes, with patients with PS II disease often being given adjuvant chemotherapy. However, with the emergence of highly effective cisplatin-based chemotherapy, the necessity of RPLND has been questioned, and active surveillance (with treatment held in reserve for those who relapse) or adjuvant chemotherapy have become the preferred management options for clinical stage (CS) I patients. It is generally agreed that all approaches ultimately result in similar cancer cure rates, approaching 100\% in most series.

\section{Surveillance}

Eleven non-randomized trials of surveillance were identified in a recent systematic review of the literature. ${ }^{39-48} \mathrm{~A}$ total of 1768 patients were evaluated and with a median follow-up range of 19.5 to 76 months, 378 recurrences were reported $(21.4 \%)$. Across the studies, 13 deaths from testicular cancer were reported, along with 7 other deaths. One of those deaths was due to treatment toxicity during 
Table 5. Summary of surveillance studies in stage I nonseminoma

\begin{tabular}{|c|c|c|c|c|c|c|}
\hline $\begin{array}{l}\text { Author (publication year) } \\
\text { Site }\end{array}$ & $\begin{array}{l}\text { Years of } \\
\text { study }\end{array}$ & $\begin{array}{l}\text { No. } \\
\text { patients }\end{array}$ & $\begin{array}{c}\text { Median } \\
\text { follow-up (mo) }\end{array}$ & $\begin{array}{l}\text { Relapses, } \\
\text { no. }(\%)\end{array}$ & $\begin{array}{l}\text { Deaths, } \\
\text { no. }(\%)\end{array}$ & DSS \\
\hline $\begin{array}{l}\text { Sturgeon [personal communication] } \\
\text { (2008) Princess Margaret Hospital, Toronto }\end{array}$ & 1981-2005 & 371 & 76 & $104(28 \%)$ & $3(1 \%)$ & $99 \%$ \\
\hline $\begin{array}{l}\text { Divrik }(2006)^{49} \\
\text { Ankara }\end{array}$ & 1993-2005 & 211 & 75 & $66(31 \%)$ & $5(2 \%)$ & $98 \%$ \\
\hline $\begin{array}{l}\text { Daugaard }(2003)^{13} \\
\text { Copenhagen }\end{array}$ & $1984-2001$ & 301 & 60 & $86(29 \%)$ & $0(0 \%)$ & $99 \%$ \\
\hline $\begin{array}{l}\text { Roeleveld }(2001)^{50} \\
\text { Amsterdam }\end{array}$ & 1982-1994 & 90 & 97 & $23(26 \%)$ & $1(1 \%)$ & $99 \%$ \\
\hline $\begin{array}{l}\text { Alexandre }(2001)^{51} \\
\text { France }\end{array}$ & 1984-1996 & 88 & 52 & $24(27 \%)$ & $1(1 \%)$ & $98 \%$ \\
\hline Francis (2000), Londo 52 & 1979-1996 & 183 & 70 & $52(28 \%)$ & $2(1 \%)$ & $99 \%$ \\
\hline $\begin{array}{l}\text { Sogani }(1998)^{53} \\
\text { Memorial Sloan-Kettering Cancer Center, NY }\end{array}$ & 1979-1987 & 105 & 136 & $27(26 \%)$ & $3(3 \%)$ & $97 \%$ \\
\hline $\begin{array}{l}\text { Colls }(1999)^{46} \\
\text { New Zealand }\end{array}$ & 1980-1997 & 248 & 53 & $70(28 \%)$ & $4(2 \%)$ & $98 \%$ \\
\hline $\begin{array}{l}\text { Hao }(1998)^{54} \\
\text { Tom Baker Cancer Centre, Calgary }\end{array}$ & 1980-1994 & 76 & 49 & $28(37 \%)$ & $2(3 \%)$ & $97 \%$ \\
\hline $\begin{array}{l}\text { Boyer }(1997)^{55} \\
\text { Australia }\end{array}$ & $1982-1995$ & 77 & 58 & $27(35 \%)$ & $2(3 \%)$ & $97 \%$ \\
\hline $\begin{array}{l}\text { Nicolai }(1995)^{56} \\
\text { Milan }\end{array}$ & 1981-1984 & 85 & 132 & $25(29 \%)$ & $3(4 \%)$ & $96 \%$ \\
\hline $\begin{array}{l}\text { Gels }(1995)^{57} \\
\text { Groningen }\end{array}$ & 1982-1992 & 154 & 84 & $42(27 \%)$ & $2(1 \%)$ & $99 \%$ \\
\hline $\begin{array}{l}\text { Ondrus and Hornak }(1994)^{58} \\
\text { Slovak Republic }\end{array}$ & 1984-1993 & 80 & 83 & $29(36 \%)$ & $4(5 \%)$ & $95 \%$ \\
\hline $\begin{array}{l}\text { Read }(1992)^{45} \\
\text { United Kingdon, }{ }^{17} \text { Denmark }^{1}\end{array}$ & 1984-1987 & 373 & 60 & $100(27 \%)$ & $5(1 \%)$ & $98 \%$ \\
\hline $\begin{array}{l}\text { Freedman }(1987)^{59} \\
\text { United Kingdom multicentre }\end{array}$ & 1979-1983 & 259 & 30 & $70(27 \%)$ & $3(1 \%)$ & $98 \%$ \\
\hline Pooled data & $1979-2005$ & 2701 & $30-136$ & $773(28.6 \%)$ & $40(1.5 \%)$ & \\
\hline $\begin{array}{l}\text { Maroto* }(2005)^{60} \\
\text { Spanish Germ Cell Group }\end{array}$ & $1994-2004$ & 358 & 40 & $71(20 \%)$ & $5(1.4 \%)$ & $95 \%$ \\
\hline $\begin{array}{l}\text { Amato* }(2004)^{61} \\
\text { M.D. Anderson Cancer Center, Houston }\end{array}$ & 1993-1999 & 23 & 38 & $3(13 \%)$ & $0(0 \%)$ & $100 \%$ \\
\hline $\begin{array}{l}\text { Ondrus* }{ }^{*}(1998)^{62} \\
\text { Slovak Republic }\end{array}$ & 1992-1997 & 49 & 37 & 7 (14.3\%) & $0(0 \%)$ & $100 \%$ \\
\hline $\begin{array}{l}\text { Klepp* }(1997)^{48} \\
\text { Sweden-Norway (Swedish-Norwegian } \\
\text { Testicular Cancer Project) }\end{array}$ & 1990-1994 & 106 & 40 & $23(22 \%)$ & $0(0 \%)$ & $100 \%$ \\
\hline $\begin{array}{l}\text { Pont* }(1990)^{47} \\
\text { Vienna }\end{array}$ & 1985-1989 & 22 & 30 & $1(4.5 \%)$ & $0(\%)$ & $100 \%$ \\
\hline $\begin{array}{l}\text { Rorth** }(1991)^{63} \\
\text { Danish Testicular Cancer Study Group }\end{array}$ & $1980-1984$ & 77 & 64 & $23(30 \%)$ & $0(0 \%)$ & $100 \%$ \\
\hline
\end{tabular}




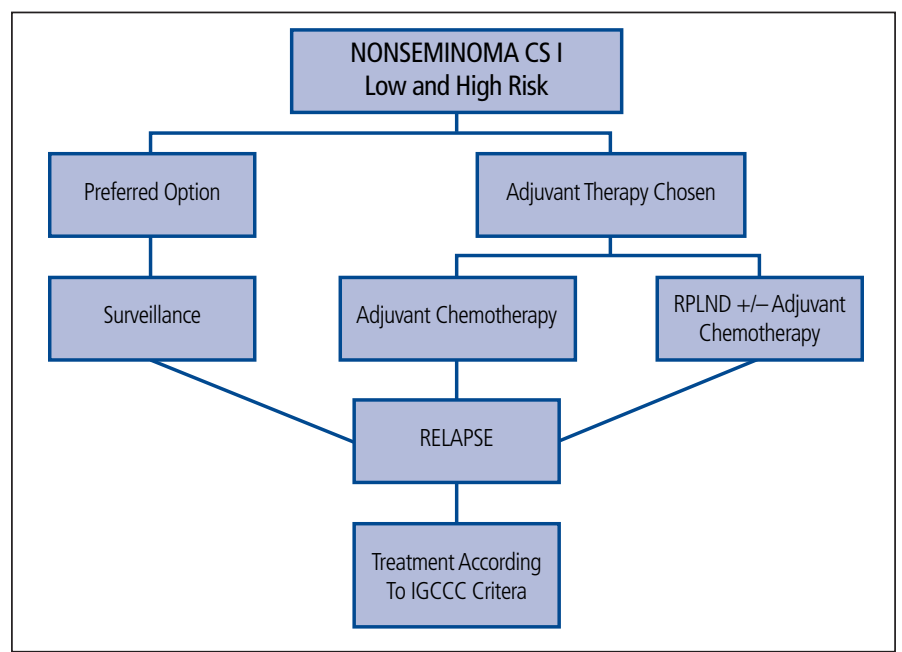

Fig 2. Schema for the management of stage I nonseminoma.

salvage treatment. The survival outcomes are summarized in Table 5. ${ }^{13,45-63}$ The presence of microscopic vascular or lymphatic invasion in the primary tumour is the most important factor predicting relapse and the presence or absence of this factor has been used to divide patients: those with high-risk disease (a third of the cases) who have about a $50 \%$ risk of relapse, and those with low-risk disease who have about a $15 \%$ to $20 \%$ risk of relapse. ${ }^{45}$

\section{Retroperiteonal lymph node dissection}

Two non-randomized studies of adjuvant RPLND in the management of stage I NSGCT were identified in a recent systematic review of the literature. ${ }^{39,48,64}$ Across these studies, 344 patients were followed for a median time ranging from 21 to 40 months, and a total of 41 recurrences were found. There was 1 death from testicular cancer and 1 other death from unrelated causes. In addition, Albers and colleagues recently reported the results of a randomized clinical trial (RCT) comparing 1 course of BEP versus RPLND in 382 patients with CS I RPLND (all risk groups). ${ }^{65}$ In the 173 patients who received RPLND, $18.5 \%$ had stage II disease at surgery and these patients were given 2 courses of BEP. In those patients treated with adjuvant chemotherapy, no relapses were observed. In patients managed with RPLND alone, 13 recurrences were observed, 7 of which occurred in the retroperitoneum. Outcomes from published studies are shown in Table 6. ${ }^{48,64-70}$

\section{Adjuvant chemotherapy}

One RCT and 7 non-randomized studies with 10 treatment arms (total 873 evaluable patients) were identified in a recent meta-analysis. ${ }^{39,48,65,71-75}$ Because the RCT compared adjuvant chemotherapy to RPLND, only the chemotherapy arm was included in the meta-analysis. Although the follow-up times of the included studies varied, all had sufficient follow-up that almost all recurrences that would occur among these patients were included. Across the 8 studies, 23 recurrences were reported, corresponding to an overall estimated recurrence rate of $3.8 \%(95 \% \mathrm{Cl}, 2.6 \%$ to $5.5 \% ; p=$ $0.42 ; 12=2.6 \%)$. For patients treated with BEP or cisplatin, vinblastine, and bleomycin (PVB), the estimated recurrence rates were $3.9 \%(95 \% \mathrm{Cl}, 1.6 \%$ to $9 \%), 3.9 \%(95 \% \mathrm{Cl}$, $2.1 \%$ to $7 \%$ ), and $7.2 \%(95 \% \mathrm{Cl}, 2.1 \%$ to $22.1 \%)$ for 1,2 , and 3 cycles of adjuvant chemotherapy, respectively. Two recurrences with 2 cycles of BEP or PVB and 1 with 3 cycles of $B E P$ were pure mature teratoma. In the randomized trial by Albers and colleagues, one course BEP versus RPLND, the two-year recurrence-free survival was $99.46 \% .{ }^{65}$ The results of the studies are summarized in Table $7.65,71,74-81$

\section{Consensus recommendations}

Patients should be informed of all treatment options, including the potential benefits and side effects of each treatment.

In a patient willing and able to adhere to a surveillance program, for all risk groups, surveillance should be considered as the management option of choice (Fig 2).

Some experts involved in the development of these recommendations suggested that RPLND may be a useful option for patients at high risk of relapse. It was agreed that there is currently not enough evidence from prospective trials to support or refute this position. Patients who undergo RPLND should have their surgery performed by surgeons who are experienced with the procedure. Otherwise, RPLND should be offered in the context of a clinical trial.

For patients who prefer immediate treatment or who are unsuitable for primary surveillance, adjuvant chemotherapy with 2 cycles of BEP is recommended, although RPLND remains an option.

\section{Stage IIA/IIB testicular nonseminoma}

The cure rate for CS IIA and IIB nonseminoma is close to $98 \%$. Three treatment options have been used in the past: primary RPLND alone, primary RPLND with adjuvant chemotherapy and primary chemotherapy followed by residual tumour resection. Primary RPLND alone has been demonstrated in high relapse rates with $30 \%$ for patients with stage IIA and $50 \%$ for patients with stage IIB disease. ${ }^{82-85}$ Primary RPLND followed by adjuvant chemotherapy with two cycles of BEP exposes all patients to two different treatment modalities including surgery-related complications, such as retrograde ejaculation. Primary chemotherapy with three cycles of BEP or, if contraindications for bleomycin, 4 cycles of etoposide and cisplatin (EP) induce a complete remission in $83 \%$ to $91 \%$ of patients with clinical stage IIA and in $61 \%$ to $87 \%$ of patients with clinical stage IIB. ${ }^{86,87}$ Most of these patients 
Table 6. Adjuvant RPLND in the management of stage I nonseminoma

\begin{tabular}{|c|c|c|c|c|c|c|c|c|}
\hline $\begin{array}{l}\text { Author (publication year) } \\
\text { Site }\end{array}$ & $\begin{array}{l}\text { Years of } \\
\text { study }\end{array}$ & $\begin{array}{l}\text { Patients } \\
\text { CS I }\end{array}$ & PS I (\%) & PS II (\%) & $\begin{array}{l}\text { Relapse } \\
\text { PS I, \% }\end{array}$ & $\begin{array}{l}\text { Relapse } \\
\text { PS II, \% }\end{array}$ & $\begin{array}{c}\text { Adjuvant } \\
\text { chemotherapy, } \\
\%\end{array}$ & $\begin{array}{l}\text { No. patients } \\
\text { dead of testis } \\
\text { cancer }(\%)\end{array}$ \\
\hline $\begin{array}{l}\text { Donohue }(1993)^{66} \\
\text { Indiana }\end{array}$ & 1979-1989 & 378 & $266(70)$ & $\begin{array}{l}112 \\
(30)\end{array}$ & $12 \%$ & $34 \%$ & $13 \%$ & $3(0.8 \%)$ \\
\hline $\begin{array}{l}\text { Sweeney }(2000)^{67} \\
\text { Indiana }\end{array}$ & 1990-1995 & 292 & $226(77)$ & $66(22)$ & $10 \%$ & $22 \%$ & $12 \%$ & $1(0.3 \%)$ \\
\hline $\begin{array}{l}\text { Nicolai }(2004)^{68} \\
\text { Milan }\end{array}$ & 1985-1995 & 322 & $262(80)$ & $60(20)$ & NR & $27 \%$ & NR & $4(1.2 \%)$ \\
\hline $\begin{array}{l}\text { Stephenson }(2005)^{69} \\
\text { MSKCC, NYC }\end{array}$ & 1989-2002 & 297 & $214(72)$ & $83(28)$ & $6 \%$ & $19 \%$ & $15 \%$ & $1(0.3 \%)$ \\
\hline $\begin{array}{l}\text { Spermon }(2002)^{193} \\
\text { Nijmegen }\end{array}$ & 1982-1994 & 101 & $70(69)$ & $31(31)$ & $10 \%$ & $0 \%$ & $31 \%$ & $1(1.0 \%)$ \\
\hline $\begin{array}{l}\text { Weissbach }(1990)^{64} \\
\text { TTSG Bonn }\end{array}$ & 1982-1987 & $\begin{array}{l}\text { (CS I } \\
\text { NR) }\end{array}$ & 229 & NR & $17 \%$ & NR & NR & 2 \\
\hline $\begin{array}{l}\text { Klepp }^{*}(1997)^{48} \\
\text { SWENOTECA }\end{array}$ & $1990-1994$ & 99 & $85(86)$ & $14(14)$ & $18 \%$ & $0 \%$ & $14 \%$ & $0(0 \%)$ \\
\hline $\begin{array}{l}\text { Albers }{ }^{* *}(2008)^{65} \\
\text { German Testicular Cancer } \\
\text { Study Group }\end{array}$ & $1996-2005$ & 173 & $141(82)$ & $32(18)$ & $9 \%$ & $0 \%$ & $18 \%$ & $0(0 \%)$ \\
\hline
\end{tabular}

CS = clinical stage; PS = pathological stage; NR = not reported; MSKCC, NYC = Memorial Sloan-Kettering Cancer Center, New York City; TTSG = Testicular Tumour Study Group;

${ }^{*}=$ indicates single arm of a risk-adapted study; ${ }^{* *}=$ indicates single arm of a randomized trial; SWENOTECA = Swedish-Norwegian Testicular Cancer Project.

can be spared a residual tumour resection and the associated morbidities, such as loss of ejaculation. In addition, relapse rates after primary chemotherapy are low with $4 \%$ to $9 \%$ for clinical stage IIA and $11 \%$ to $15 \%$ for clinical stage IIB disease. ${ }^{86,87}$ Patients with elevated serum tumour AFP, HCG or $\mathrm{LDH}$ and/or CS IIB are therefore treated with primary chemotherapy according to the algorithms for patients with advanced disease, according to International Germ Cell Cancer Collaborative Group (IGCCCG) recommendations. ${ }^{10,69,88}$

Patients without marker elevations but with retroperitoneal lymph nodes 1 to $2 \mathrm{~cm}$, suspected to be CS IIA, represent a particular problem. Differential diagnosis in these patients includes benign lymph node enlargement but also teratoma or active germ cell cancer. None of the currently used imaging methods including positron emission tomography (PET) scanning and magnetic resonance imaging (MRI) can reliably identify patients with metastases. Three options can be considered for these patients: RPLND, surveillance or primary chemotherapy. With RPLND, the pathological stage can be verified immediately, although $10 \%$ to $40 \%$ of patients will have non-malignant histology and PS I disease. ${ }^{69,87,89}$ If surveillance is chosen, follow-up imaging after 6 weeks is indicated to document whether the lesion grows, remains stable or shrinks. A shrinking lesion is likely to be not of malignant origin and should be further observed. A stable or growing lesion indicates either teratoma or undifferentiated malignant tumour. If the lesion grows slowly and without corresponding increase of the tumour markers, RPLND should be performed by an experienced surgeon because of suspected teratoma. Patients with a rapidly growing lesion and/or a concomitant increase of the tumour, markers should not be resected but treated with primary BEP chemotherapy according to the treatment algorithm for patients with metastatic disease and IGCCCG recommendations. ${ }^{90-92}$

When RPLND is performed this should be done using a full template nerve-sparing technique. ${ }^{69}$

Further options after RPLND are surveillance or adjuvant chemotherapy. For patients with PS IIA and B, the risk of recurrence is $30 \%$ and $50 \%$, respectively, with surveillance only. ${ }^{82,85,87,93-95}$ Relapses occur almost exclusively outside the retroperitoneum. Adjuvant chemotherapy with 2 cycles of BEP in all PS IIA/B patients after RPLND reduces this risk of recurrence to about 0 to $7 \% .{ }^{82,87}$ Yet, adjuvant chemotherapy represents an overtreatment in 50\% to $70 \%$ of radically operated PS IIA/B patients with the resulting treatment-related toxicity and possible late sequelae.

\section{Consensus recommendations}

Patients with CS IIA marker positive disease and IIB regardless of marker state should be managed with primary chemotherapy.

Patients with IIA disease without marker elevation can be managed by: 
Wood et al.

Table 7. Adjuvant chemotherapy for stage I nonseminoma germ cell tumour (selected studies)

\begin{tabular}{|c|c|c|c|c|c|}
\hline $\begin{array}{l}\text { Author } \\
\text { (publication year) }\end{array}$ & $\begin{array}{c}\text { No. } \\
\text { patients }\end{array}$ & $\begin{array}{c}\text { Risk } \\
\text { factors }\end{array}$ & Regimen & $\begin{array}{c}\text { Median } \\
\text { follow-up (mo) }\end{array}$ & Relapses \\
\hline \multicolumn{6}{|c|}{ Adjuvant chemotherapy with 2 cycles of cisplatin-based combination chemotherapy } \\
\hline Oliver et al $(1992)^{76}$ & 22 & $\begin{array}{c}\mathrm{EC}, \mathrm{VI}, \text { no yolk sac } \\
\text { tumour }\end{array}$ & $\mathrm{EBC} 3 \mathrm{i} \times 2$ & 43 & $1(5 \%)$ \\
\hline Madej et al. $(1991)^{77}$ & 30 & $\begin{array}{l}\mathrm{VI}, \mathrm{LI}, \mathrm{RT} \text { invasion, } \\
\text { involvement of } \\
\text { epidydimis }\end{array}$ & PVB $\times 3$ & NR & 0 \\
\hline Pont et al. (1996) $)^{75}$ & 29 & VI & $\mathrm{BEP} \times 2$ & 79 & $2(6.9 \%)$ \\
\hline Cullen et al. $(1996)^{74}$ & 114 & $\begin{array}{l}\mathrm{EC}, \mathrm{VI}, \text { no yolk sac } \\
\text { tumour }\end{array}$ & $\mathrm{BEP} \times 2$ & 48 & $2(1.7 \%)$ \\
\hline Studer et al. $(2000)^{78}$ & 59 & $\begin{array}{l}\mathrm{EC}, \mathrm{VI} \text {, capsule } \\
\text { penetration }\end{array}$ & PVB or BEP $\times 2$ & 93 & $2(3 \%)$ \\
\hline $\begin{array}{l}\text { Chevreau et al. } \\
(2004)^{79}\end{array}$ & 40 & VI, EC & $\mathrm{BEP} \times 2$ & 113 & 0 \\
\hline $\begin{array}{l}\text { Dearnaley et al. } \\
(2005)^{71}\end{array}$ & 115 & $\begin{array}{c}\mathrm{EC}, \mathrm{VI}, \text { no yolk sac } \\
\text { tumour }\end{array}$ & $\mathrm{BOP} \times 2$ & 70 & $2(1.7 \%)$ \\
\hline \multicolumn{6}{|c|}{ Adjuvant chemotherapy with 1 cycle of BEP (experimental) } \\
\hline Gilbert et al. $(2006)^{80}$ & 22 & $\begin{array}{l}\text { VI, EC, LI, no Yolk } \\
\text { sac tumour }\end{array}$ & $\begin{array}{l}\mathrm{BEP} \times 1 \\
\mathrm{CEB} \times 1\end{array}$ & 122 & 0 \\
\hline Albers et al. $(2008)^{65}$ & 191 & $\mathrm{VI}$ & $\mathrm{BEP} \times 1$ & 56 & $2(1 \%)$ \\
\hline $\begin{array}{l}\text { Westermann et al. } \\
(2008)^{81}\end{array}$ & 40 & VI, LI, EC & $\mathrm{BEP} \times 1$ & 99 & $1(2.5 \%)$ \\
\hline
\end{tabular}

$\mathrm{EC}=$ embryonal component; $\mathrm{VI}=$ vascular invasion; $\mathrm{LI}=$ lymphatic invasion; $\mathrm{RT}=$ rete testes; $\mathrm{NR}=$ not reported; $\mathrm{EBC}=$ etoposide, bleomycin, and carboplatin; $\mathrm{PVB}=$ cisplatin $[\mathrm{Platinol}-\mathrm{AO}]$ vinblastine, bleomycin; $\mathrm{BEP}=$ bleomycin, etoposide, platinum; $\mathrm{BOP}=$ bleomycin, vincristine, cisplatin; $\mathrm{CEB}$ = carboplatin, etoposide and bleomycin.

1. RPLND with consideration of adjuvant chemotherapy if node positive.

2. Surveillance with surgery for stable or growing lesions (if becomes marker positive use primary chemotherapy approach.

\section{Treatment of advanced or metastatic disease}

Patients with advanced or metastatic GCTs should always be considered potentially curable. Survival outcomes appear to be better in specialized centres and this may be related to experience, case selection, volume, and/or the organization of multidisciplinary care. ${ }^{4,11,96}$ Referral of all patients with advanced GCTs for consultation to a specialized centre is strongly recommended. Patients with advanced disease can be stratified into three prognostic groups using the IGCCC criteria (Table 2b). ${ }^{10}$ Prognostic variables include histology (nonseminoma vs. seminoma), site of the primary testicular (retroperitoneal and other), presence or absence of non-pulmonary visceral metastases (brain, bone or liver) and degree of marker elevation (AFP, $\beta$-HCG and LDH).
Standard chemotherapy for all patients is BEP chemotherapy ${ }^{97-100}$ The efficacy of the 5-day schedule of BEP with etoposide $100 \mathrm{mg} / \mathrm{m}^{2} /$ day and cisplatin $20 \mathrm{mg} / \mathrm{m}^{2} /$ day for 5 days and bleomycin 30 IU weekly is of equivalent efficacy to the same drugs given on a 3-day schedule (etoposide $165 \mathrm{mg} / \mathrm{m}^{2} /$ day given for 3 days, cisplatin $50 \mathrm{mg} / \mathrm{m}^{2} /$ day given for 2 days, and bleomycin $30 \mathrm{IU}$ weekly. ${ }^{99} \mathrm{BEP}$ given over 3 days, however, has increased short-term gastrointestinal toxicity and long-term ototoxicity. ${ }^{99,101}$ Carboplatin should not be substituted for cisplatin due to inferior outcomes. ${ }^{102,103}$ Thus, the original 5-day BEP regimen, therefore, is the preferred option for the management of advanced GCTs. Modifications in BEP to reduce toxicity or improve convenience should be avoided as they may also reduce efficacy. A summary of the randomized trials in advanced disease is shown in Table 8.

In patients with IGCCC "good" prognosis disease, 3 cycles of BEP should be given. ${ }^{97,98,104,105}$ If there is a contraindication to bleomycin, 4 cycles of EP can be given, but has been associated with a nonstatistically significant but higher death rate in one RCT. ${ }^{100,106,107}$ 
In patients with IGCCC "intermediate" or "poor" prognosis disease, 4 cycles of the BEP are considered the standard therapy. ${ }^{108,109}$ etoposide, ifosfamide and cisplatin (VIP) has been compared to BEP in this patient population and shows similar cancer outcomes but more genitourinary toxicity and myelosuppression and, thus, represents an alternative to BEP for patients with a contraindication to bleomycin or who develop pulmonary compromise while receiving BEP. ${ }^{110}$ For "intermediate" or "poor" prognosis patients, there is no evidence to date that the use of highdose chemotherapy with autologous stem cell transplant is superior to standard BEP for 4 cycles. ${ }^{111,112}$ When chemotherapy is given, it should be given without dose reductions at 21-day intervals. Only in exceptional circumstances should the chemotherapy be delayed or dose-reduced. Primary prophylaxis for complications of neutropenia with granulocyte-colony stimulating factor is generally not recommended as per the American Society of Clinical Oncology 2006 Evidence-Based Clinical Practice Guidelines. ${ }^{113}$ In this guideline, primary prophylaxis is not recommended if the risk of febrile neutropenia is less than 20\%; however, it can be considered in patients that are at high risk based on age, co-morbidities, disease characteristics and myelotoxicity of the regimen (i.e., ifosfamide-based chemotherapy). Secondary prophylaxis can be considered if there were infectious complications in the prior cycle and to maintain dense intensity. ${ }^{114}$ Prophylactic antibiotic treatment has been shown to reduce febrile neutropenia during chemotherapy with no change in mortality and may be considered in some patients. ${ }^{115,116}$

In patients with life-threatening "poor" prognosis disease, orchiectomy should not delay the initiation of curative therapy and can be performed at the end of therapy. ${ }^{117-120}$ It is recommended that these patients be referred to specialized centres for optimal multidisciplinary management and supportive care.

\section{Monitoring during chemotherapy}

During chemotherapy, monitoring tumour markers just prior to each treatment cycle is mandatory. If there is no tumour marker elevation prior to chemotherapy, radiological imaging should be performed after 2 cycles.

As long as tumour markers are declining, a full course of chemotherapy should be completed. If there is a slow tumour marker decline or stable tumour markers, earlier radiological restaging can be considered. If there is unequivocal tumour marker rise, even in the presence of radiological regression, a switch to salvage chemotherapy may be necessary. Patients in this setting, who have evidence of progressive disease with first-line chemotherapy, have a worse prognosis. ${ }^{121}$

If there is an expected tumour marker decline but the metastases are growing radiologically, growing teratoma syndrome should be considered..$^{92,122}$ In most cases, the full course of chemotherapy should be completed and resection of the growing and residual masses should be done post-chemotherapy. Very rarely, rapid radiological progression in the setting of decreasing tumour marker decline is seen which would necessitate surgical resection prior to the completion of chemotherapy.

Post-chemotherapy, radiological restaging should be performed in all patients. If the expected tumour marker decline is seen, all residual masses should be treated appropriately. If the tumour markers plateau and are at a low level, they should be followed closely. If there is a persistent plateau or tumour marker decline, residual masses should be treated appropriately.

It is not uncommon for patients with a markedly elevated HCG prior to treatment to take longer for the HCG to normalize or plateau at the end of chemotherapy. ${ }^{123}$

\section{Post-chemotherapy residual masses: nonseminomatous germ cell tumours}

In many patients who have completed chemotherapy and have normalized their tumour markers, residual masses are seen on repeat radiological imaging. Histology of residual masses after first-line chemotherapy will be necrosis in $40 \%$ to $50 \%$, mature teratoma in $35 \%$ to $40 \%$ and viable cancer in $10 \%$ to $15 \% .{ }^{124,125}$ The incidence of viable cancer is likely even higher after salvage chemotherapy. ${ }^{124,126}$ Some of the factors that have been found to predict for no viable tumour in the residual mass include: no teratoma in the primary tumour, pre-chemotherapy normal tumour markers, a small pre-chemotherapy mass, a large shrinkage of the mass with chemotherapy, and size of residual mass $\leq 10$ mm. ${ }^{125,127,128}$ To date, however, no imaging procedures, including PET scan, nor any one predictive factor or predictive model exists to reliably predict the histology of residual masses. ${ }^{125,127-133}$

In patients with normal tumour markers and residual masses, the residual masses should be resected. Two areas of controversy exist, however, where the literature does not give clear answers: (1) what constitutes a "residual mass" and (2) the extent of surgical resection. No consensus could be reached on the first controversy. All Canadian genitourinary oncology specialists felt that a full discussion regarding the risks and benefits of surgery post-chemotherapy must be undertaken with all patients and individual factors, such as the risk of relapse, ability for follow-up, quality of life and patient preferences, must be taken in to account. All felt the radiological imaging had to be reviewed by experienced and knowledgeable radiologists, uro-oncologists and/or medical oncologists. All Canadian genitourinary oncology specialists thought any residual mass $\geq 1 \mathrm{~cm}$ should be resected. ${ }^{126}$ Some thought that any residual mass should 
Wood et al.

Table 8. Summary of randomized studies in advanced germ cell tumours

\begin{tabular}{|c|c|c|c|c|c|}
\hline Author & Year & Risk stratification & No. patients & Treatment & Results \\
\hline \multicolumn{6}{|c|}{ Good-risk patients } \\
\hline Bosl $^{106}$ & 1988 & MSKCC & 164 & $\begin{array}{l}\mathrm{EP} \times 4 \\
\mathrm{VABcC} \mathrm{C} \times 4\end{array}$ & $\begin{array}{l}\text { No difference } \\
\text { EP less toxic }\end{array}$ \\
\hline Einhorn ${ }^{98}$ & 1989 & Indiana & 184 & $\begin{array}{l}\mathrm{BEP} \times 3 \\
\mathrm{BEP} \times 4\end{array}$ & $\begin{array}{l}\text { No difference } \\
\text { BEP } \times 3 \text { less toxic }\end{array}$ \\
\hline de Wit ${ }^{99}$ & 2001 & MRC/EORTC & 812 & $\begin{array}{l}B E P \times 3 \\
B E P \times 4\end{array}$ & $\begin{array}{l}\text { No difference } \\
\text { BEP } \times 3 \text { less toxic } \\
5 \text { days less toxic vs. } 3 \text { days }\end{array}$ \\
\hline Culine $^{100}$ & 2007 & $\begin{array}{l}\text { Institut Gustave } \\
\text { Roussy }\end{array}$ & 262 & $\begin{array}{l}\mathrm{BEP} \times 3 \\
\mathrm{EP} \times 4\end{array}$ & $\begin{array}{l}\text { Equivalent RR } \\
\text { Survival underpowered }\end{array}$ \\
\hline \multicolumn{6}{|c|}{ Role of bleomycin in good-risk patients } \\
\hline Levi $^{194}$ & 1993 & AGCTG & 218 & $\begin{array}{l}\text { PVP } \\
\text { VP }\end{array}$ & $\begin{array}{l}\text { Equivalent RR but less } \\
\text { cancer deaths with PVB }\end{array}$ \\
\hline Loehrer ${ }^{105}$ & 1995 & Indiana & 171 & $\begin{array}{l}\mathrm{BEP} \times 3 \\
\mathrm{EP} \times 3\end{array}$ & BEP $\times 3$ superior \\
\hline de Wit ${ }^{195}$ & 1997 & IGCCC & 395 & $\begin{array}{l}\mathrm{BE} 360 \mathrm{P} \times 4 \\
\mathrm{E} 360 \mathrm{P} \times 4\end{array}$ & $\mathrm{BE}_{360} \mathrm{P} \times 4$ superior \\
\hline Culine $^{100}$ & 2007 & $\begin{array}{l}\text { Institut Gustave } \\
\text { Roussy }\end{array}$ & 262 & $\begin{array}{l}\mathrm{BEP} \times 3 \\
\mathrm{EP} \times 4\end{array}$ & $\begin{array}{l}\text { Equivalent RR } \\
\text { Survival underpowered }\end{array}$ \\
\hline \multicolumn{6}{|c|}{ Role of carboplatin } \\
\hline Bajorin $^{103}$ & 1993 & $\begin{array}{l}\text { MSKCC Good } \\
\text { Risk }\end{array}$ & 265 & $\begin{array}{l}\mathrm{EP} \times 4 \\
\text { E Carbo } \times 4\end{array}$ & EP $\times 4$ superior \\
\hline Horowich ${ }^{102}$ & 1997 & $\begin{array}{l}\text { MRC/EORTC } \\
\text { Good Risk }\end{array}$ & 598 & $\begin{array}{l}\mathrm{BE}_{360} \mathrm{P} \times 4 \\
\mathrm{BE}_{360} \text { Carbo } \times 4\end{array}$ & BE360P $\times 4$ superior \\
\hline \multicolumn{6}{|c|}{ Intermediate and poor risk } \\
\hline Nichols ${ }^{108}$ & 1998 & $\begin{array}{l}\text { Indiana Advanced } \\
\text { (= IGCCC- } \\
\text { intermediate and } \\
\text { poor) }\end{array}$ & 304 & $\begin{array}{l}\mathrm{BEP} \times 4 \\
\mathrm{VIP} \times 4\end{array}$ & $\begin{array}{l}\text { No difference } \\
\text { BEP } \times 4 \text { less toxic }\end{array}$ \\
\hline de Wit ${ }^{110}$ & 1998 & $\begin{array}{l}\text { IGCCC (good, } \\
\text { intermediate, } \\
\text { poor) }\end{array}$ & 84 & $\begin{array}{l}\mathrm{BEP} \times 4 \\
\mathrm{VIP} \times 4\end{array}$ & No difference (closed early) \\
\hline $\operatorname{Droz}^{112}$ & 2007 & $\begin{array}{l}\text { IGCCC } \\
\text { (intermediate, } \\
\text { poor) }\end{array}$ & 114 & $\begin{array}{l}\mathrm{PVeB} \times 4 \\
\mathrm{HDCT}\end{array}$ & No difference \\
\hline Motzer ${ }^{111}$ & 2007 & $\begin{array}{l}\text { IGCCC } \\
\text { (intermediate, } \\
\text { poor) }\end{array}$ & 219 & $\begin{array}{l}\mathrm{BEP} \times 4 \\
\mathrm{HDCT}\end{array}$ & No difference \\
\hline
\end{tabular}

be resected including those smaller than $1 \mathrm{~cm} .{ }^{134} \mathrm{~A}$ small minority felt that even patients with completely normal radiologically imaging should undergo RPLND to try to prevent late relapses. ${ }^{135,136}$

If one were to decide on a RPLND, historically different options for the extent of resection have been recommended.
These include: (1) removal of the visible or palpable mass and then a limited RPLND, (2) a strategy guided by intraoperative findings such that if the frozen section showed teratoma or viable cancer, a full bilateral RPLND would be done and if only fibrosis or necrosis is seen, a limited RPLND would be performed, (3) a modified RPLND in selected patients, 
(4) or a full bilateral RPLND in all patients. ${ }^{137-142}$ Most Canadian genitourinary oncology specialists felt that in the setting of post-chemotherapy residual masses, a full bilateral RPLND should be done in most cases; however, this decision must be reviewed carefully in each individual patient.

If persistent retroperitoneal disease is present and the decision to perform a RPLND is made, surgery should be done 4 to 8 weeks after completing chemotherapy. Whatever the extent of surgery, complete resection of the residual masses impacts prognosis and every attempt at complete surgical resection must be made. ${ }^{126,132,143}$ If technically possible, a nerve-sparing procedure should be done. Surgery should be performed by trained, experienced, expert uro-oncologists which may require referral to specialist centre. Perioperative and postoperative complications must also be minimized, especially pulmonary toxicity in patients who have received bleomycin. ${ }^{144}$ Laparoscopic RPLND should not be considered a standard of care at the present time. ${ }^{145-147}$

Resection of residual tumour outside the retroperitoneum should be considered on an individual basis. In most cases, the retroperitoneum should be operated on first. Concordance in the pathology between the retroperitoneum and other metastatic sites ranges from $50 \%$ to $89 \%{ }^{148-152}$ Thus, if the histology in the resected residual retroperitoneal masses shows complete necrosis, both surveillance and resection of the remaining non-retroperitoneal residual lesions are acceptable options. If the histology in the resected residual retroperitoneal masses shows mature teratoma, resection of the remaining non-retroperitoneal masses should be done. If the histology in the resected residual retroperitoneal masses shows viable malignancy, salvage chemotherapy and/or further surgery may be options depending on the individual clinical scenario.

\section{Post-chemotherapy residual masses: seminoma}

Post-chemotherapy residual masses in advanced seminoma are not uncommon and most do not have to be treated. In patients with residual masses $\geq 3 \mathrm{~cm}$, an FDG-PET scan should be obtained to gain further information regarding the viability of the residual mass. ${ }^{153,154}$ In patients with residual masses less than $3 \mathrm{~cm}$, the likelihood of viable malignancy is low and thus surveillance is reasonable. ${ }^{155-157}$ In patients with residual masses less than $<3 \mathrm{~cm}$, the use of FDG-PET scanning is optional. The PET scan should be done 4 to 12 weeks after day 21 of the last chemotherapy cycle.

If the PET scan is negative, no other active treatment is required and the patient can be surveyed. If the PET scan is positive, however, one must consider the possibility of viable disease. The Canadian consensus was that surgical resection is the management of choice. ${ }^{158,159}$ Radiation therapy may be given in some cases although the overall benefit of radiotherapy may be minimal. ${ }^{160}$ The advantages of surgery include the ability to assess the response to chemotherapy, stage accurately and potentially provide cure. The disadvantage of surgery is the high frequency of desmoplastic reaction associated with seminoma which may make surgery more technically difficult and increase complication rates. ${ }^{161}$ The extent of surgical resection in seminoma is usually a resection of the residual mass or multiple biopsies and does not usually include a full or modified RPLND.

\section{Consolidation chemotherapy after secondary surgery}

If the pathology from completely resected residual masses shows necrosis or mature teratoma, no further treatment is required. When viable cancer is found, the role of further chemotherapy is not clear. One retrospective analysis showed an improvement in progression-free survival with adjuvant chemotherapy however no improvement in overall survival. ${ }^{162}$ A second retrospective analysis also showed a longer disease-free interval in those patients who had viable cancer in their post-chemotherapy RPLND who received chemotherapy compared to those who did not. ${ }^{124}$ There are no direct prospective data to help guide the decision.

\section{Brain metastases}

About $2 \%$ to $3 \%$ of patients with germ cell malignancy will present with brain metastases and up to $10 \%$ to $15 \%$ may develop it during the course of their illness. There are three patterns of presentations: (1) at the time of initial diagnosis in the presence of other systemic disease, (2) at relapse in the brain only, (3) at relapse including the brain and other sites of systemic disease. ${ }^{163,164}$ Patients who present with brain metastases at their initial diagnosis have a survival probability in the range of $30 \%$, whereas patients who develop brain metastases as one of multiple sites of relapse have a shorter survival. ${ }^{164}$ The patients that appear to have the best outcome are those with isolated brain metastases at the time of recurrence; although this is a rare group. ${ }^{25,165,166}$ The optimal sequence of chemotherapy, radiotherapy and surgery is not known and management should be performed on an individual basis. In a multivariate analysis, radiotherapy together with chemotherapy improved the overall prognosis of patients who present with brain metastases versus either treatment alone, which is different than another report showing no benefit from the addition of radiotherapy. ${ }^{25,166}$ If the goal is cure, systemic chemotherapy should be used in all patients. It is not clear whether high-dose chemotherapy is of greater benefit to these patients. ${ }^{167}$ The roles of secondary resection of a solitary residual mass in the brain and the use of brain radiotherapy are also unclear. 
Wood et al.

\section{Consensus recommendations}

All patients with advanced GCT should be treated for cure and referral to specialized centre should be strongly considered.

Patients with IGCCC good-risk disease should receive 3 cycles of BEP.

Patients with IGCCC intermediate and poor-risk disease should receive 4 cycles of BEP.

During chemotherapy, patients need to be monitored on a regular basis with serial tumour marker estimation. Post-chemotherapy, all patients should have radiological restaging to determine if there are residual masses.

In NSGCT cases, post-chemotherapy residual masses greater than $1 \mathrm{~cm}$ should be resected.

No consensus could be reached on role of surgical resection of masses $\leq 1 \mathrm{~cm}$ or where complete response is achieved.

If surgery performed for residual disease a full bilateral RPLND should be performed

Residual mass post-treatment seminoma:

1. Greater than $3 \mathrm{~cm}$ with PET scan positive: surgical resection.

2. $\leq 3 \mathrm{~cm}$ or greater than $3 \mathrm{~cm}$ with PET scan negative: observe.

Patients with brain metastases should be managed in a specialized centre and may require multimodality treatment including surgical resection.

\section{Treatment of relapsed and refractory disease}

Patients with GCTs who relapse represent a heterogeneous group of patients. Depending on the histology and initial presenting stage, patients may either relapse while on surveillance, post-radiation therapy, post-RPLND or postchemotherapy.

\section{Chemotherapy naïve}

Nonseminoma patients may relapse while on surveillance or post primary RPLND for clinical stage I disease. Seminoma patients may relapse after adjuvant carboplatin chemotherapy, adjuvant radiation therapy or while on surveillance. Seminoma patients who relapse while on surveillance or after adjuvant carboplatin may be candidates for radiation therapy if the relapse is localized to the RPLN and if they meet the criteria for radiation therapy as per stage II seminoma.

All other patients should be risk stratified into by the IGCCCG criteria and treated accordingly with standard dose BEP. Seminoma patients who have previously received only radiation therapy have an excellent chance of cure with standard dosed cisplatin-based chemotherapy. ${ }^{168}$

\section{Relapse post-cisplatin-based chemotherapy}

Patients who relapse after cisplatin-based chemotherapy can be treated with either further standard dose chemotherapy or consideration of high-dose chemotherapy (HDCT) and autologous stem cell transplantation (ASCT). In this patient population, prognostic factors have been identified that affect outcome. These are similar, but not identical to, those factors used to risk-stratify chemotherapy-naïve patients. These factors include: site of the primary cancer (gonadal better than non-gonadal); histology of the primary tumour (seminoma better than nonseminoma); response to firstline cisplatin-based chemotherapy (complete response or partial response marker negative better than partial response marker positive or progressive disease); progression-free interval after first-line chemotherapy (greater than 6 months better than less than 6 months); sites of metastatic disease prior to salvage treatment (lung or nodal better than other visceral sites of disease); and level of tumour markers at relapse (AFP $<100 / \mathrm{ng} / \mathrm{mL}, \mathrm{HCG}<1000 \mathrm{u} / \mathrm{L}$ as opposed to higher than this). ${ }^{169-174}$

No data exits as to whether or not or how one could tailor the approach to treating relapsed patients based on these prognostic factors. However, consensus participants noted that many of the phase II trials of standard dose chemotherapy have largely been conducted in good-risk patients, making it difficult to extrapolate results to the poor risk population.

\section{Standard dose chemotherapy}

Regimens of choice for standard dose salvage treatment include 4 cycles of either VIP, Vinblastine, ifosfamide and cisplatin (VeIP) or Paclitaxel, ifosfamide and cisplatin (TIP). ${ }^{170,171,173,175-179}$ With these regimens, long-term disease control can be achieved in between $15 \%$ to $60 \%$ of patients. Given that no randomized trials exist comparing these chemotherapy combinations, no recommendation can be made as to which regimen is superior or should be used as the standard management. Most of the older data with VIP and VeIP is in all-risk patients and most of the newer data with TIP is in good-risk patients at relapse. Thus, it is less certain if the data in good-risk relapsed patients with TIP would be as useful in determining a regimen in the poorer risk population; however, it is not an unreasonable choice.

There has been one randomized trial of HDCT versus standard dose salvage chemotherapy in good-risk relapsed patients. This trial compared 4 cycles of cisplatin, ifosfamide and etoposide (or vinblastine) (PEI) compared to 3 cycles of PEI followed by high dose carboplatin, etoposide and cyclophosphamide and ASCT. This trial showed no advantage to HDCT in this group. ${ }^{174}$ 


\section{High-dose chemotherapy and autologous transplantation}

High-dose chemotherapy has been shown in phase II trials to be an effective salvage strategy in poor-risk patients with a suggestion of an improvement in survival as compared to standard dose salvage chemotherapy, albeit through matched-pair analysis rather than randomized trials. ${ }^{180,181}$ High-dose chemotherapy has also been shown to be a potentially curative option for patients with second or subsequent relapses. ${ }^{181-183}$

Patients who failed to be cured with a standard dose option and are well enough to tolerate it, HDCT with transplantation should be offered before declaring the relapsed disease incurable. For patients undergoing HDCT, high dose carboplatin and etoposide regimen is the conditioning regimen of choice. ${ }^{184}$ While there have been no randomized studies that have determined the optimal conditioning regimen, there have been reports of excess toxicity if an oxazaphosphorine (e.g., cyclophosphamide) is included in the regimen. ${ }^{183,184}$ Also, not including a third drug in the regimen allows higher doses of the two most active agents (carboplatin and etoposide) to be administered. Patients who are proceeding to transplant should be offered standard dose chemotherapy before the transplant to determine if they have chemotherapy sensitive disease, to debulk the disease before the transplant, and to keep the disease under control while logistical arrangements for the transplant can be put into place. It appears the best results for HDCT have been obtained if a tandem transplant has been performed and thus, patients should have enough stem cells collected for a planned tandem procedure. ${ }^{184}$ High-dose chemotherapy and transplantation should be performed in specialized centres where there is adequate volume and expertise to be able to offer the best supportive and pre/post transplant care.

\section{Multiply refractory patients}

Patients who relapse after standard dose and high dose chemotherapy may still respond to chemotherapy agents, usually with a view to palliating the disease rather than curing it. Drugs having efficacy include oral etoposide, paclitaxel, gemcitabine, oxaliplatin or combinations of these drugs. ${ }^{185}$ While infrequent, some patients being treated in the third-line setting may have long-term disease control or cure in particular if the tumour lesions can be completely resected. ${ }^{184}$

\section{Salvage surgery}

In patients who normalize their markers but have residual disease radiographically, all residual masses should be considered for salvage surgery. Patients who still harbor viable disease in their post-chemotherapy masses have a worse prognosis but the administration of adjuvant chemotherapy does not appear to improve outcomes in this setting. ${ }^{143,186}$

Patients who fail to normalize their markers or have progressive disease post-salvage systemic treatment may be candidates for salvage or "desperation" surgery if it is felt that all the disease can be resected. This will often require a multidisciplinary surgical team and should be performed by surgeons skilled in these operations working in specialized centres.

\section{Later relapses}

Late relapse is defined as disease recurrence more than 2 years after completion of first-line therapy. The risk of late relapse in all comers is approximately $1.5 \%$ for seminoma and $3 \%$ for nonseminoma patients. ${ }^{187}$ These patients have disease that is more chemotherapy resistant and immediate surgical resection of recurrent disease should be undertaken if feasible, irrespective of the level of tumour markers. ${ }^{188-192}$ If surgical resection is not feasible, biopsy of the lesions should be undertaken to determine the histology and chemotherapy should be administered directed to the histology that is found on biopsy. If viable GCT is found, TIP has shown activity in late relapsers who were not surgical candidates. ${ }^{173}$

\section{Relapsing patients with mediastinal primary}

Patients with mediastinal primary GCT who relapse have a poor prognosis. In transplant series, very few if any of these patients have successfully been salvaged with a transplant, yet the toxicities of the treatment are still present.

\section{Consensus recommendations}

Seminoma patients who relapse while on surveillance or after adjuvant carboplatin may be candidates for radiation therapy if the relapse is localized to the RPLN and meets the criteria for radiation therapy as per stage II seminoma recommendations.

All other chemotherapy-naïve relapse patients should be stratified by the IGCCCG criteria and treated accordingly to the recommendations for first-line management of advanced GCT.

Patients who relapse after cisplatin-based chemotherapy can be treated with either further standard dose chemotherapy or consideration of high-dose chemotherapy and autologous stem cell transplantation (HDCT with ASCT).

No evidence that either approach is better.

Many in the group felt that it would be reasonable to offer standard dose chemotherapy to good-risk patients as many will be cured, especially based on the more recent 
Wood et al.

data using TIP, and reserve the transplant for third line.

For patients undergoing HDCT, high dose carboplatin and etoposide regimen is the conditioning regimen of choice.

High-dose chemotherapy and transplantation could be offered as third-line therapy.

Patients who relapse after standard dose and high-dose chemotherapy should be offered third-line treatment as longterm disease control may still be achieved.

Salvage surgery should always be considered in patients with residual resectable disease.

Patients with late relapse (nonseminoma) should have surgical resection of disease if possible.

Patients with mediastinal primary GCT who relapse should rarely if ever be offered transplantation.

“Division of Medical Oncology, Queen Elizabeth II Health Sciences Centre, Halifax, NS; 'Department of Medical Oncology, British Columbia Cancer Agency, Vancouver, BC; ;Division of Urology, University Health Network, University of Toronto, Toronto, ON; \&Department of Radiation Oncology, Radiation Medicine Program, Princess Margareet Hospital, University of Toronto, Toronto, $\mathrm{ON}$; 'Division of Medical Oncology, Juravinski Cancer Centre, Hamilton, ON; ${ }^{*}$ Department of Medical Imaging, University Health Network, University of Toronto, Toronto, ON; " Department of Pathology, University Health Network, University of Toronto, Toronto, $\mathrm{ON}$; ${ }^{\beta}$ Department of Medicine, London Health Sciences Centre, London, ON; a Department of Medical Oncology, Cross Cancer Institute, Edmonton, $A B$; ${ }^{\Delta}$ Department of Radiation Oncology, Vancouver Cancer Clinic, Vancouver, BC; "Division of Medical Oncology, McGill University Health Centre, Montréal, QC; ${ }^{* *}$ Department of Medicine, Division of Medical Oncology, The OHtawa Hospital Regional Cancer Centre, Ottawa, ON; ${ }^{\dagger t}$ Department of Medicine, University of Toronto, Princess Margaret Hospital, Toronto, ON; ;

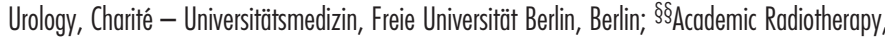
Institute of Cancer Research and Royal Marsden Hospital, Sutton, Surrey; ${ }^{ \pm 0}$ Oregon Health \& Science University Cancer Institute, Portland, OR

Competing interests: None declared.

This paper has been peer-reviewed.

\section{References}

1. International Agency for Reseach on Cancer. World Health Organization. Available at: http://wwwdep.iarc.fr/. Accessed March 9, 2010.

2. McGlynn KA, Devesa SS, Sigurdson AJ, et al. Trends in the incidence of testicular germ cell tumour s in the United States. Cancer 2003;97:63-70.

3. Canadian Cancer Society. Available at: www.cancer.ca. Accessed March 17, 2010.

4. Collette L, Sylvester RJ, Stenning SP, et al. Impact of the treating institution on survival of patients with "poor-prognosis" metastatic nonseminoma. European Organization for Research and Treatment of Cancer Genito-Urinary Tract Cancer Collaborative Group and the Medical Research Council Testicular Cancer Working Party. J Natl Cancer Inst 1999;91:839-46.

5. Schmoll HJ, Souchon R, Krege S, et al. European consensus on diagnosis and treatment of germ cell cancer: a report of the European Germ Cell Cancer Consensus Group (EGCCCG). Ann Oncol 2004;15:1377-99.

6. Krege S, Beyer J, Souchon $R$, et al. European consensus conference on diagnosis and treatment of germ cell cancer: a report of the second meeting of the European Germ Cell Cancer Consensus group (EGCCCG): part I. Eur Urol 2008;53:478-96.

7. Krege S, Beyer J, Souchon R, et al. European consensus conference on diagnosis and treatment of germ cell cancer: a report of the second meeting of the European Germ Cell Cancer Consensus Group (EGCCCG): part II. Eur Urol 2008;53:497-513.
8. Richie JP. Impact of diagnostic delay in testis cancer: Results of a large population-based study: Huyghe E, Muller A, Mieusset R, Bujan L, Bachaud JM, Chevreau C, Plante P, Thonneau P, Human Fertility Research Group, Paule de Viguier Hospital, Toulouse University III, France; Urology and Andrology Department, Paule de Viguier Hospital, Toulouse, France. Urol Oncol 2008;26:220-1.

9. Sobin LH, Wittekind $\mathrm{CH}$, eds. TNM classification of malignant tumours (UICC). $6^{\text {th }}$ ed. Hoboken, NJ: Wiley, John \& Sons; 2002

10. International Germ Cell Consensus Classification: a prognostic factor-based staging system for metastatic germ cell cancers. International Germ Cell Cancer Collaborative Group. J Clin Oncol 1997;15:594-603.

11. Aass N, Klepp 0, Cavallin-Stahl E, et al. Prognostic factors in unselected patients with nonseminomatous metastatic testicular cancer: a multicenter experience. J Clin Oncol 1991;9:818-26.

12. Winstanley AM, Mikuz G, Debruyne F, et al. Handling and reporting of biopsy and surgical specimens of testicular cancer. Eur Urol 2004;45:564-73.

13. Daugaard G, Petersen PM, Rorth M. Surveillance in stage I testicular cancer. Apmis 2003;111:76-83; discussion 83-75.

14. Germa-Lluch JR, Garcia del Muro X, Maroto P, et al. Clinical pattern and therapeutic results achieved in 1490 patients with germ-cell tumours of the testis: the experience of the Spanish Germ-Cell Cancer Group (GG). Eur Urol 2002;42:553-62; discussion 562-3.

15. Horwich A, Alsanjari N, A'Hern R, et al. Surveillance following orchidectomy for stage I testicular seminoma. Br J Cancer 1992;65:775-8.

16. Oliver R, Boubilkova L, Ong J. Fifteen-year follow-up of the Anglian Germ Cell Cancer group adjuvant studies of carboplatin as an alternative to radiation or surveillance for stage 1 seminoma. Proc ASCO 2001;19Abstract 780.

17. Ramakrishnan S, Champion AE, Dorreen MS, et al. Stage I seminoma of the testis: is post-orchidectomy surveillance a safe alternative to routine postoperative radiotherapy? Clin Oncol (R Coll Radiol) 1992;4:284-6.

18. von der Maase H, Specht L, Jacobsen GK, et al. Surveillance following orchidectomy for stage I seminoma of the testis. Eur J Cancer 1993;29A:1931-4.

19. Warde PR, Chung P, Sturgeon J, et al. Should surveillance be considered the standard of care in stage I seminoma? J Clin Oncol 2005;23(16suppl):4520.

20. Tyldesley S, Voduc D, McKenzie M, et al. Surveillance of stage I testicular seminoma: British Columbia Cancer Agency Experience 1992 to 2002. Urology 2006;67:594-8.

21. Warde P, Specht L, Horwich A, et al. Prognostic factors for relapse in stage I seminoma managed by surveillance: a pooled analysis. J Clin Oncol 2002;20:4448-52.

22. Aparicio J, Germa JR, Garcia del Muro X, et al. Risk-adapted management for patients with clinical stage I seminoma: the Second Spanish Germ Cell Cancer Cooperative Group study. I Clin Oncol 2005;23:8717-23.

23. Bayens YC, Helle PA, Van Putten WL, et al. Orchidectomy followed by radiotherapy in 176 stage I and II testicular seminoma patients: benefits of a 10-year follow-up study. Radiother Oncol 1992;25:97-102.

24. Coleman JM, Coleman RE, Turner AR, et al. The management and clinical course of testicular seminoma: 15 years' experience at a single institution. Clin Oncol (R Coll Radiol) 1998;10:237-41.

25. Fossa SD, Bokemeyer C, Gerl A, et al. Treatment outcome of patients with brain metastases from malignant germ cell tumour s. Cancer 1999;85:988-97.

26. Jones WG, Fossa SD, Mead GM, et al. Randomized trial of 30 versus 20 Gy in the adjuvant treatment of stage I Testicular Seminoma: a report on Medical Research Council Trial TE18, European Organisation for the Research and Treatment of Cancer Trial 30942 (ISRCTN18525328). J Clin Oncol 2005;23:1200-8.

27. Santoni R, Barbera F, Bertoni F, et al. Stage I seminoma of the testis: a bi-institutional retrospective analysis of patients treated with radiation therapy only. BJU Int 2003;92:47-52; discussion 52.

28. Warde P, Gospodarowicz MK, Panzarella T, et al. Stage I testicular seminoma: results of adjuvant irradiation and surveillance. J Clin Oncol 1995; 13:2255-62.

29. Fossa SD, Horwich A, Russell JM, et al. Optimal planning target volume for stage I testicular seminoma: A Medical Research Council randomized trial. Medical Research Council Testicular Tumour Working Group. J Clin Oncol 1999;17:1146.

30. Logue JP, Harris MA, Livsey JE, et al. Short course paraaortic radiation for stage I seminoma of the testis. Int J Radiat Oncol Biol Phys 2003:57:1304-9.

31. Huddart RA, Norman A, Shahidi M, et al. Cardiovascular disease as a long-term complication of treatment for testicular cancer. J Clin Oncol 2003;21:1513-23.

32. Zagars GK, Ballo MT, Lee AK, et al. Mortality after cure of testicular seminoma. J Clin Oncol 2004;22:640-7.

33. van Leeuwen FE, Stiggelbout AM, van den Belt-Dusebout AW, et al. Second cancer risk following testicular cancer: a follow-up study of 1,909 patients. J Clin Oncol 1993;11:415-24.

34. Moller H, Friis S, Kjaer SK. Survival of Danish cancer patients 1943-1987. Male genital organs. APMIS Suppl 1993;33:122-36

35. Travis LB, Fossa SD, Schonfeld SJ, et al. Second cancers among 40,576 testicular cancer patients: focus on long-term survivors. J Natl Cancer Inst 2005;97:1354-65. 
36. van den Belt-Dusebout AW, de Wit R, Gietema JA, et al. Treatment-specific risks of second malignancies and cardiovascular disease in 5-year survivors of testicular cancer. J Clin Oncol 2007;25:4370-8.

37. Oliver RT, Ong J, Shamash J, et al. Long-term follow-up of Anglian Germ Cell Cancer Group surveillance versus patients with Stage 1 nonseminoma treated with adjuvant chemotherapy. Urology 2004;63:556-61.

38. Steiner H, Muller T, Gozzi C, et al. Two cycles of cisplatin-based chemotherapy for low-volume retroperitoneal stage II nonseminomatous germ cell tumours. BJU Int 2006;98:349-52.

39. Hotte S, Mayhew LA, Jewett M, et al. Cancer Care Ontario. Management of Stage I Nonseminomatous Testicular Cancer: Guideline Recommendations. Available at www.cancercare.on.ca/pdf/pebc3-19s.pdf. Accessed March 9, 2010.

40. Read G, Johnson RJ, Wilkinson PM, et al. Prospective study of follow up alone in stage I teratoma of the testis. Br Med J (Clin Res Ed) 1983;287:1503-5.

41. Sogani PC, Whitmore WF Jr, Herr HW, et al. Orchiectomy alone in the treatment of clinical stage I nonseminomatous germ cell tumour of the testis. I Clin Oncol 1984;2:267-70.

42. Pizzocaro G, Zanoni F, Milani A, et al. Orchiectomy alone in clinical stage I nonseminomatous testis cancer: a critical appraisal. J Clin Oncol 1986;4:35-40.

43. Peckham MJ, Brada M. Surveillance following orchidectomy for stage I testicular cancer. Int I Androl 1987; 10:247-54

44. Sturgeon JF, Jewett MA, Alison RE, et al. Surveillance after orchidectomy for patients with clinical stage I nonseminomatous testis tumour s. J Clin Oncol 1992;10:564-8.

45. Read G, Stenning SP, Cullen MH, et al. Medical Research Council prospective study of surveillance for stage I testicular teratoma. Medical Research Council Testicular Tumour s Working Party. I Clin Oncol 1992;10:1762-8

46. Colls BM, Harvey VJ, Skelton L, et al. Late results of surveillance of clinical stage I nonseminoma germ cell testicular tumours: 17 years' experience in a national study in New Zealand. BJU Int 1999:83:76-82.

47. Pont J, Holt W, Kosak D, et al. Risk-adapted treatment choice in stage I nonseminomatous testicular germ cell cancer by regarding vascular invasion in the primary tumour : a prospective trial. J Clin Oncol 1990;8:16-20

48. Klepp 0, Dahl 0, Flodgren $P$, et al. Risk-adapted treatment of clinical stage 1 non-seminoma testis cancer. Eur I Cancer 1997;33:1038-44.

49. Divrik RT, Akdogan B, Ozen $\mathrm{H}$, et al. Outcomes of surveillance protocol of clinical stage I nonseminomatous germ cell tumour s-is shift to risk adapted policy justified? J Urol 2006;176 (4 Pt 1):1424-9; discussion 1429-30.

50. Roeleveld TA, Horenblas $S$, Meinhardt W, et al. Surveillance can be the standard of care for stage I nonseminomatous testicular tumour $s$ and even high risk patients. J Urol 2001;166:2166-70.

51. Alexandre J, Fizazi K, Mahe C, et al. Stage I non-seminomatous germ-cell tumours of the testis: identification of a subgroup of patients with a very low risk of relapse. Eur I Cancer 2001;37:576-82.

52. Francis R, Bower $M$, Brunstrom $G$, et al. Surveillance for stage I testicular germ cell tumours: results and cost benefit analysis of management options. Eur J Cancer 2000;36:1925-32.

53. Sogani PC, Perrotti M, Herr HW, et al. Clinical stage I testis cancer: long-term outcome of patients on surveillance. J Urol 1998; 159:855-8.

54. Hao D, Seidel J, Brant R, et al. Compliance of clinical stage I nonseminomatous germ cell tumour patients with surveillance. J Urol 1998;160(3 Pt 1):768-71.

55. Boyer MJ, Cox K, Tattersall MH, et al. Active surveillance after orchiectomy for nonseminomatous testicular germ cell tumour s: late relapse may occur. Urology 1997:50:588-92.

56. Nicolai N, Pizzocaro G. A surveillance study of clinical stage I nonseminomatous germ cell tumour $s$ of the testis: 10-year followup. I Urol 1995;154:1045-9.

57. Gels ME, Hoekstra HJ, Sleiifer DT, et al. Detection of recurrence in patients with clinical stage I nonseminomatous testicular germ cell tumour s and consequences for further follow-up: a single-center 10 year experience. J Clin Oncol 1995; 13:1188-94.

58. Ondrus $\mathrm{D}$, Hornak $M$. Orchiectomy alone for clinical stage I nonseminomatous germ cell tumour $s$ of the testis (NSGCT): a minimum follow-up period of 5 years. Tumour $i$ 1994; 80:362-4.

59. Freedman LS, Parkinson MC, Jones WG, et al. Histopathology in the prediction of relapse of patients with stage I testicular teratoma treated by orchidectomy alone. Lancet 1987;2:294-8.

60. Maroto P, Garcia del Muro X, Aparicio J, et al. Multicentre risk-adapted management for stage I nonseminomatous germ cell tumours. Ann Oncol 2005;16:1915-20.

61. Amato RJ, Ro JY, Ayala AG, et al. Risk-adapted treatment for patients with clinical stage I nonseminomatous germ cell tumour of the testis. Urology 2004;63:144-8; discussion 148-9.

62. Ondrus D, Matoska J, Belan V, et al. Prognostic factors in clinical stage I nonseminomatous germ cell testicular tumour s: rationale for different risk-adapted treatment. Eur Urol 1998;33:562-6.

63. Rorth M, Jacobsen GK, von der Maase H, et al. Surveillance alone versus radiotherapy after orchiectomy for clinical stage I nonseminomatous testicular cancer. Danish Testicular Cancer Study Group. J Clin Oncol 1991;9:1543-8.
64. Weissbach L, Boedefeld EA, Horstmann-Dubral B. Surgical treatment of stage-I non-seminomatous germ cell testis tumour . Final results of a prospective multicenter trial 1982-1987. Testicular Tumour Study Group. Eur Urol 1990;17:97-106.

65. Albers P, Siener R, Krege S, et al. Randomized Phase III Trial Comparing Retroperitoneal Lymph Node Dissection With One Course of Bleomycin and Etoposide Plus Cisplatin Chemotherapy in the Adjuvant Treatment of Clinical Stage I Nonseminomatous Testicular Germ Cell Tumour s: AUO Trial AH 01/94 by the German Testicular Cancer Study Group. J Clin Oncol 2008;26:2966-72.

66. Donohue JP, Thornhill JA, Foster RS, et al. Retroperitoneal lymphadenectomy for clinical stage A testis cancer (1965 to 1989): modifications of technique and impact on ejaculation. J Urol 1993;149:237-43.

67. Sweeney CJ, Hermans BP, Heilman DK, et al. Results and outcome of retroperitoneal lymph node dissection for clinical stage I embryonal carcinoma — predominant testis cancer. J Clin Oncol 2000; 18:358-62

68. Nicolai N, Miceli R, Artusi R, et al. A simple model for predicting nodal metastasis in patients with clinical stage I nonseminomatous germ cell testicular tumour s undergoing retroperitoneal lymph node dissection only. J Urol 2004;171:172-6.

69. Stephenson AJ, BosI GJ, Bajorin DF, et al. Retroperitoneal lymph node dissection in patients with low stage testicular cancer with embryonal carcinoma predominance and/or lymphovascular invasion. J Urol 2005; 174:557-60; discussion 560.

70. Spermon JR, Roeleveld TA, van der Poel HG, et al. Comparison of surveillance and retroperitoneal lymph node dissection in Stage I nonseminomatous germ cell tumour s. Urology 2002:59:923-9.

71. Dearnaley DP, Fossa SD, Kaye SB, et al. Adjuvant bleomycin, vincristine and cisplatin (BOP) for highrisk stage I non-seminomatous germ cell tumours: a prospective trial (MRC TE17). Br J Cancer 2005:92:2107-13.

72. Pectasides D, Skarlos D, Dimopoulos AM, et al. Two cycles of carboplatin-based adjuvant chemotherapy for high-risk clinical stage I and stage IM non-seminomatous germ cell tumours of the testis: a HECOG trial. Anticancer Res 2003;23:4239-44.

73. Bohlen D, Borner M, Sonntag RW, et al. Long-term results following adjuvant chemotherapy in patients with clinical stage I testicular nonseminomatous malignant germ cell tumour $s$ with high risk factors. $J$ Urol 1999;161:1148-52.

74. Cullen MH, Stenning SP, Parkinson MC, et al. Short-course adjuvant chemotherapy in high-risk stage I nonseminomatous germ cell tumour s of the testis: a Medical Research Council report. J Clin Oncol 1996;14:1106-13.

75. Pont J, Albrecht W, Postner $G$, et al. Adjuvant chemotherapy for high-risk clinical stage I nonseminomotous testicular germ cell cancer: long-term results of a prospective trial. J Clin Oncol 1996;14:441-8.

76. Oliver RT, Raja MA, Ong J, et al. Pilot study to evaluate impact of a policy of adjuvant chemotherapy for high risk stage 1 malignant teratoma on overall relapse rate of stage 1 cancer patients. I Urol 1992; 148:1453-5; discussion 1455-6.

77. Madej G, Pawinski A. Risk-related adjuvant chemotherapy for stage I non-seminoma of the testis. Clin Oncol (R Coll Radiol) 1991;3:270-2.

78. Studer UE, Burkhard FC, Sonntag RW. Risk adapted management with adjuvant chemotherapy in patients with high risk clinical stage i nonseminomatous germ cell tumour .J Urol 2000;163:1785-7.

79. Chevreau C, Mazerolles C, Soulie M, et al. Long-term efficacy of two cycles of BEP regimen in high-risk stage I nonseminomatous testicular germ cell tumour $s$ with embryonal carcinoma and/or vascular invasion. Eur Urol 2004;46:209-14; discussion 214-5.

80. Gilbert DC, Norman AR, Nicholl I, et al. Treating stage I nonseminomatous germ cell tumours with a single cycle of chemotherapy. BJU Int 2006;98:67-9.

81. Westermann DH, Schefer H, Thalmann GN, et al. Long-erm followup results of 1 cycle of adjuvant bleomycin, etoposide and cisplatin chemotherapy for high risk clinical stage I nonseminomatous germ cell tumour s of the testis. J Urol 2008; 179:163-6.

82. Williams SD, Stablein DM, Einhorn LH, et al. Immediate adjuvant chemotherapy versus observation with treatment at relapse in pathological stage II testicular cancer. N Engl J Med 1987;317:1433-8.

83. Weissbach L, Hartlapp JH. Adjuvant chemotherapy of metastatic stage II nonseminomatous testis tumour. J Urol 1991; 146:1295-8

84. Donohue JP, Thornhill JA, Foster RS, et al. The role of retroperitoneal lymphadenectomy in clinical stage B testis cancer: the Indiana University experience (1965 to 1989). J Urol 1995;153:85-9.

85. Kennedy BJ, Torkelson JL, Fraley EE. Adjuvant chemotherapy for stage II nonseminomatous germ cell cancer of the testis. Cancer 1994;73:1485-9.

86. Kuczyk M, Machtens S, Stief C, et al. Management of the post-chemotherapy residual mass in patients with advanced stage non-seminomatous germ cell tumour s (NSGCT). Int J Cancer 1999;83:852-5.

87. Weissbach L, Bussar-Maatz R, Flechtner H, et al. RPLND or primary chemotherapy in clinical stage IIA/B nonseminomatous germ cell tumour s? Results of a prospective multicenter trial including quality of life assessment. Eur Urol 2000:37:582-94.

88. Stephenson AJ, Bosl GJ, Motzer RJ, et al. Nonrandomized comparison of primary chemotherapy and retroperitoneal lymph node dissection for clinical stage IIA and IIB nonseminomatous germ cell testicular cancer. J Clin Oncol 2007:25:5597-602. 
Wood et al.

89. Sheinfeld J, Motzer RJ, Rabbani F, et al. Incidence and clinical outcome of patients with teratoma in the retroperitoneum following primary retroperitoneal lymph node dissection for clinical stages I and IIA nonseminomatous germ cell tumour s. J Urol 2003;170(4 Pt 1):1159-62.

90. Horwich A, Stenning S. Initial chemotherapy for stage II testicular non-seminoma. World I Urol 1994;12:148-50

91. Peckham MJ, Hendry WF. Clinical stage II non-seminomatous germ cell testicular tumours. Results of management by primary chemotherapy. Br J Urol 1985;57:763-8.

92. Logothetis CJ, Samuels ML, Selig DE, et al. Primary chemotherapy followed by a selective retroperitoneal lymphadenectomy in the management of clinical stage II testicular carcinoma: a preliminary report. J Urol 1985; 134:1127-30.

93. Pizzocaro G, Monfardini S. No adjuvant chemotherapy in selected patients with pathologic stage II nonseminomatous germ cell tumour s of the testis. J Urol 1984;131:677-80.

94. Pizzocaro G, Piva L, Salvioni R, et al. Adjuvant chemotherapy in resected stage-ll nonseminomatous germ cell tumour s of testis. In which cases is it necessary? Eur Urol 1984;10:151-8.

95. Kondagunta GV, Sheinfeld J, Mazumdar M, et al. Relapse-free and overall survival in patients with pathologic stage II nonseminomatous germ cell cancer treated with etoposide and cisplatin adjuvant chemotherapy. I Clin Oncol 2004;22:464-7.

96. Fever EJ, Frey CM, Brawley OW, et al. After a treatment breakthrough: a comparison of trial and population-based data for advanced testicular cancer. J Clin Oncol 1994;12:368-77.

97. Saxman SB, Finch D, Gonin R, et al. Long-term follow-up of a phase III study of three versus four cycles of bleomycin, etoposide, and cisplatin in favorable-prognosis germ-cell tumour s: the Indian University experience. J Clin Oncol 1998:16:702-6.

98. Einhorn LH, Williams SD, Loehrer PJ, et al. Evaluation of optimal duration of chemotherapy in favorableprognosis disseminated germ cell tumour s: a Southeastern Cancer Study Group protocol. J Clin Oncol 1989;7:387-91.

99. de Wit R, Roberts JT, Wilkinson PM, et al. Equivalence of three or four cycles of bleomycin, etoposide, and cisplatin chemotherapy and of a 3- or 5-day schedule in good-prognosis germ cell cancer: a randomized study of the European Organization for Research and Treatment of Cancer Genitourinary Tract Cancer Cooperative Group and the Medical Research Council. J Clin Oncol 2001;19:1629-40.

100. Culine $S$, Kerbrat $P$, Kramar A, et al. Refining the optimal chemotherapy regimen for good-risk metastatic nonseminomatous germ-cell tumour s: a randomized trial of the Genito-Urinary Group of the French Federation of Cancer Centers (GETUG T93BP). Ann Oncol 2007;18:917-24.

101. Fossa SD, de Wit R, Roberts JT, et al. Quality of life in good prognosis patients with metastatic germ cell cancer: a prospective study of the European Organization for Research and Treatment of Cancer Genitourinary Group/Medical Research Council Testicular Cancer Study Group (30941/TE20). J Clin Oncol 2003;21:1107-18.

102. Horwich A, Sleifer DT, Fossa SD, et al. Randomized trial of bleomycin, etoposide, and cisplatin compared with bleomycin, etoposide, and carboplatin in good-prognosis metastatic nonseminomatous germ cell cancer: a Multiinstitutional Medical Research Council/European Organization for Research and Treatment of Cancer Trial. J Clin Oncol 1997:15:1844-52.

103. Bajorin DF, Sarosdy MF, Pfister DG, et al. Randomized trial of etoposide and cisplatin versus etoposide and carboplatin in patients with good-risk germ cell tumour s: a multiinstitutional study. I Clin Oncol 1993;11:598-606.

104. Toner GC, Stockler MR, Boyer MJ, et al. Comparison of two standard chemotherapy regimens for goodprognosis germ-cell tumours: a randomised trial. Australian and New Zealand Germ Cell Trial Group. Lancet 2001;357:739-45.

105. Loehrer PJ Sr, Johnson D, Elson P, et al. Importance of bleomycin in favorable-prognosis disseminated germ cell tumour s: an Eastern Cooperative Oncology Group trial. J Clin Oncol 1995; 13:470-6.

106. Bosl GJ, Geller NL, Bajorin D, et al. A randomized trial of etoposide + cisplatin versus vinblastine + bleomycin + cisplatin + cyclophosphamide + dactinomycin in patients with good-prognosis germ cell tumours. I Clin Oncol 1988;6:1231-8.

107. Xiao H, Mazumdar M, Bajorin DF, et al. Long-term follow-up of patients with good-risk germ cell tumour s treated with etoposide and cisplatin. I Clin Oncol 1997;15:2553-8.

108. Nichols CR, Catalano PJ, Crawford ED, et al. Randomized comparison of cisplatin and etoposide and either bleomycin or ifosfamide in treatment of advanced disseminated germ cell tumour s: an Eastern Cooperative Oncology Group, Southwest Oncology Group, and Cancer and Leukemia Group B Study. J Clin Oncol 1998:16:1287-93

109. de Wit R, Collette L, Sylvester R, et al. Serum alpha-fetoprotein surge after the initiation of chemotherapy for non-seminomatous testicular cancer has an adverse prognostic significance. Br J Cancer 1998; 78:1350-5.

110. de Wit R, Stoter G, Sleiffer DT, et al. Four cycles of BEP vs four cycles of VIP in patients with intermediate-prognosis metastatic testicular non-seminoma: a randomized study of the EORTC Genitourinary Tract Cancer Cooperative Group. European Organization for Research and Treatment of Cancer. Br I Cancer $1998 ; 78: 828-32$
111. Motzer RJ, Nichols CJ, Margolin KA, et al. Phase III randomized trial of conventional-dose chemotherapy with or without high-dose chemotherapy and autologous hematopoietic stem-cell rescue as first-line treatment for patients with poor-prognosis metastatic germ cell tumour s. J Clin Oncol 2007;25:247-56.

112. Droz JP, Kramar A, Biron P, et al. Failure of high-dose cyclophosphamide and etoposide combined with double-dose cisplatin and bone marrow support in patients with high-volume metastatic nonseminomatous germ-cell tumours: mature results of a randomised trial. Eur Urol 2007;51:739-46; discussion 747-8.

113. Smith TJ, Khatcheressian J, Lyman GH, et al. 2006 update of recommendations for the use of white blood cell growth factors: an evidence-based clinical practice guideline. J Clin Oncol 2006;24:3187-205.

114. Fossa SD, Kaye SB, Mead GM, et al. Filgrastim during combination chemotherapy of patients with poorprognosis metastatic germ cell malignancy. European Organization for Research and Treatment of Cancer, Genito-Urinary Group, and the Medical Research Council Testicular Cancer Working Party, Cambridge, United Kingdom. J Clin Oncol 1998;16:716-24.

115. Cullen M, Steven N, Billingham L, et al. Antibacterial prophylaxis after chemotherapy for solid tumour s and lymphomas. N Engl J Med 2005;353:988-98.

116. Cullen MH, Billingham LJ, Gaunt CH, et al. Rational selection of patients for antibacterial prophylaxis after chemotherapy. J Clin Oncol 2007:25:4821-8.

117. Chong C, Logothetis CJ, von Eschenbach A, et al. Orchiectomy in advanced germ cell cancer following intensive chemotherapy: a comparison of systemic to testicular response. J Urol 1986;136:1221-3.

118. Leibovitch I, Baniel J, Rowland RG, et al. Malignant testicular neoplasms in immunosuppressed patients. J Urol 1996;155:1938-42

119. Ondrus D, Hornak M, Breza J, et al. Delayed orchiectomy after chemotherapy in patients with advanced testicular cancer. Int Urol Nephrol 2001:32:665-7.

120. Simmonds PD, Mead GM, Lee AH, et al. Orchiectomy after chemotherapy in patients with metastatic testicular cancer. Is it indicated? Cancer 1995;75:1018-24.

121. Fossa SD, Stenning SP, Gerl A, et al. Prognostic factors in patients progressing after cisplatin-based chemotherapy for malignant non-seminomatous germ cell tumours. Br I Cancer 1999;80:1392-9.

122. Andre F, Fizazi K, Culine $\mathrm{S}$, et al. The growing teratoma syndrome: results of therapy and long-term follow-up of 33 patients. Eur J Cancer 2000;36:1389-94.

123. Zon RT, Nichols C, Einhorn LH. Management strategies and outcomes of germ cell tumour patients with very high human chorionic gonadotropin levels. J Clin Oncol 1998;16:1294-7.

124. Fox EP, Weathers TD, Williams SD, et al. Outcome analysis for patients with persistent nonteratomatous germ cell tumour in postchemotherapy retroperitoneal lymph node dissections. I Clin Oncol 1993;11:1294-9.

125. Toner GC, Panicek DM, Heelan RT, et al. Adjunctive surgery after chemotherapy for nonseminomatous germ cell tumour s: recommendations for patient selection. J Clin Oncol 1990;8:1683-94.

126. Hendry WF, Norman AR, Dearnaley DP, et al. Metastatic nonseminomatous germ cell tumours of the testis: results of elective and salvage surgery for patients with residual retroperitoneal masses. Cancer 2002;94:1668-76.

127. Carver BS, Bianco FJ Jr, Shayegan B, et al. Predicting teratoma in the retroperitoneum in men undergoing post-chemotherapy retroperitoneal lymph node dissection. J Urol 2006; 176:100-3; discussion 103-4.

128. Donohue JP, Rowland RG, Kopecky K, et al. Correlation of computerized tomographic changes and histological findings in 80 patients having radical retroperitoneal lymph node dissection after chemotherapy for testis cancer. J Urol 1987;137:1176-9.

129. Debono DJ, Heilman DK, Einhorn LH, et al. Decision analysis for avoiding postchemotherapy surgery in patients with disseminated nonseminomatous germ cell tumour s. J Clin Oncol 1997;15:1455-64.

130. Vergouwe Y, Steyerberg EW, de Wit R, et al. External validity of a prediction rule for residual mass histology in testicular cancer: an evaluation for good prognosis patients. Br J Cancer 2003;88:843-7.

131. Steyerberg EW, Keizer HJ, Habbema JD. Prediction models for the histology of residual masses after chemotherapy for metastatic testicular cancer. ReHiT Study Group. Int I Cancer 1999;83:856-9.

132. Steyerberg EW, Keizer HJ, Fossa SD, et al. Prediction of residual retroperitoneal mass histology after chemotherapy for metastatic nonseminomatous germ cell tumour : multivariate analysis of individual patient data from six study groups. I Clin Oncol 1995;13:1177-87.

133. Vergouwe Y, Steyerberg EW, Foster RS, et al. Predicting retroperitoneal histology in postchemotherapy testicular germ cell cancer: a model update and multicentre validation with more than 1000 patients. Eur Urol 2007:51:424-32.

134. Oldenburg J, Alfsen GC, Lien HH, et al. Postchemotherapy retroperitoneal surgery remains necessary in patients with nonseminomatous testicular cancer and minimal residual tumour masses. I Clin Oncol 2003;21:3310-7.

135. Fossa SD, Ous S, Lien HH, et al. Post-chemotherapy lymph node histology in radiologically normal patients with metastatic nonseminomatous testicular cancer. J Urol 1989;141:557-9.

136. Carver BS, Shayegan B, Serio A, et al. Long-term clinical outcome after postchemotherapy retroperitoneal lymph node dissection in men with residual teratoma. J Clin Oncol 2007;25:1033-7. 
137. Hendry WF, A'Hern RP, Hetherington JW, et al. Paraaortic lymphadenectomy after chemotherapy for metastatic non-seminomatous germ cell tumours: prognostic value and therapeutic benefit. $\mathrm{Br} J \mathrm{Urol}$ $1993 ; 71: 208-13$

138. Aprikian AG, Herr HW, Bajorin DF, et al. Resection of postchemotherapy residual masses and limited retroperitoneal lymphadenectomy in patients with metastatic testicular nonseminomatous germ cell tumour s. Cancer 1994;74:1329-34.

139. Wood DP Jr, Herr HW, Heller G, et al. Distribution of retroperitoneal metastases after chemotherapy in patients with nonseminomatous germ cell tumour s. J Urol 1992; 148:1812-5; discussion 1815-6.

140. Rabbani F, Goldenberg SL, Gleave ME, et al. Retroperitoneal lymphadenectomy for post-chemotherapy residual masses: is a modified dissection and resection of residual masses sufficient? $\mathrm{Br} J$ Urol 1998;81:295-300.

141. Beck SD, Foster RS, Bihrle R, et al. Is full bilateral retroperitoneal lymph node dissection always necessary for postchemotherapy residual tumour? Cancer 2007;110:1235-40.

142. Carver BS, Shayegan B, Eggener $S$, et al. Incidence of metastatic nonseminomatous germ cell tumour outside the boundaries of a modified postchemotherapy retroperitoneal lymph node dissection. J Clin Oncol 2007;25:4365-9.

143. Stenning SP, Parkinson MC, Fisher $C$, et al. Postchemotherapy residual masses in germ cell tumour patients: content, clinical features, and prognosis. Medical Research Council Testicular Tumour Working Party. Cancer 1998;83:1409-19.

144. Baniel J, Foster RS, Rowland RG, et al. Complications of post-chemotherapy retroperitoneal lymph node dissection. J Urol 1995;153(3 Pt 2):976-80.

145. Rassweiler JJ, Frede T, Lenz E, et al. Long-term experience with laparoscopic retroperitoneal lymph node dissection in the management of low-stage testis cancer. Eur Urol 2000;37:251-60.

146. Janetschek G, Peschel R, Hobisch A, et al. Laparoscopic retroperitoneal lymph node dissection. J Endourol 2001;15:449-53; discussion 453-5.

147. Steiner H, Peschel R, Janetschek G, et al. Long-term results of laparoscopic retroperitoneal lymph node dissection: a single-center 10-year experience. Urology 2004;63:550-5.

148. Hartmann JT, Candelaria M, Kuczyk MA, et al. Comparison of histological results from the resection of residual masses at different sites after chemotherapy for metastatic non-seminomatous germ cell tumours. Eur J Cancer 1997;33:843-7.

149. Steyerberg EW, Donohue JP, Gerl A, et al. Residual masses after chemotherapy for metastatic testicular cancer: the clinical implications of the association between retroperitoneal and pulmonary histology. Reanalysis of Histology in Testicular Cancer (ReHiT) Study Group. J Urol 1997:158:474-8.

150. Tognoni PG, Foster RS, McGraw P, et al. Combined post-chemotherapy retroperitoneal lymph node dissection and resection of chest tumour under the same anesthetic is appropriate based on morbidity and tumour pathology. J Urol 1998; 159:1833-5.

151. Gels ME, Hoekstra HJ, Sleiffer DT, et al. Thoracotomy for postchemotherapy resection of pulmonary residual tumour mass in patients with nonseminomatous testicular germ cell tumour s: aggressive surgical resection is justified. Chest 1997; 112:967-73

152. Brenner PC, Herr HW, Morse MJ, et al. Simultaneous retroperitoneal, thoracic, and cervical resection of postchemotherapy residual masses in patients with metastatic nonseminomatous germ cell tumour $s$ of the testis. J Clin Oncol 1996;14:1765-9.

153. De Santis M, Bokemeyer C, Becherer A, et al. Predictive impact of 2-18fluoro-2-deoxy-D-glucose positron emission tomography for residual postchemotherapy masses in patients with bulky seminoma. J Clin Oncol 2001; 19:3740-4.

154. De Santis M, Becherer A, Bokemeyer C, et al. 2-18fluoro-deoxy-D-glucose positron emission tomography is a reliable predictor for viable tumour in postchemotherapy seminoma: an update of the prospective multicentric SEMPET trial. J Clin Oncol 2004;22:1034-9.

155. Albers $P$, Weissbach L, Krege $S$, et al. Prediction of necrosis after chemotherapy of advanced germ cell tumour s: results of a prospective multicenter trial of the German Testicular Cancer Study Group. I Urol 2004:171:1835-8.

156. Herr HW, Sheinfeld J, Puc HS, et al. Surgery for a post-chemotherapy residual mass in seminoma. J Urol 1997; 157:860-2.

157. Ravi R, Ong J, Oliver RT, et al. The management of residual masses after chemotherapy in metastatic seminoma. BJU Int 1999:83:649-53

158. Puc HS, Heelan R, Mazumdar M, et al. Management of residual mass in advanced seminoma: results and recommendations from the Memorial Sloan-Kettering Cancer Center. J Clin Oncol 1996;14:454-60.

159. Hofmockel G, Gruss A, Theiss M. Chemotherapy in advanced seminoma and the role of postcytostatic retroperitoneal lymph node dissection. Urol Int 1996;57:38-42.

160. Duchesne GM, Stenning SP, Aass N, et al. Radiotherapy after chemotherapy for metastatic seminoma—a diminishing role. MRC Testicular Tumour Working Party. Eur J Cancer 1997;33:829-35.

161. Mosharafa AA, Foster RS, Leibovitch BC. Is the postchemotherapy resection of seminomatous elements associated with higher acute morbidity? J Urol 2002;167:172.
162. Fizazi K, Tjulandin S, Salvioni R, et al. Viable malignant cells after primary chemotherapy for disseminated nonseminomatous germ cell tumour $s$ : prognostic factors and role of postsurgery chemotherapy—results from an international study group. J Clin Oncol 2001;19:2647-57.

163. Azar JM, Schneider BP, Einhorn LH. Is the blood-brain barrier relevant in metastatic germ cell tumour ? Int J Radiat Oncol Biol Phys 2007;69:163-6.

164. Spears WT, Morphis IG 2nd, Lester SG, et al. Brain metastases and testicular tumour s: long-term survival. Int J Radiat Oncol Biol Phys 1992;22:17-22.

165. Bokemeyer C, Nowak P, Haupt A, et al. Treatment of brain metastases in patients with testicular cancer. J Clin Oncol 1997;15:1449-54.

166. Hartmann JT, Bamberg M, Albers P. Multidisciplinary treatement and prognosis of patients with central nervous metastases (CNS) from testicular germ cell tumour (GCT) origin. Proc Am Soc Clin Oncol 2003;22:400.

167. Kollmannsberger C, Nichols C, Bamberg M, et al. First-line high-dose chemotherapy +/- radiation therapy in patients with metastatic germ-cell cancer and brain metastases. Ann Oncol 2000;11:553-9.

168. Miller KD, Loehrer PJ, Gonin R, et al. Salvage chemotherapy with vinblastine, ifosfamide, and cisplatin in recurrent seminoma. J Clin Oncol 1997;15:1427-31.

169. Schmoll HJ, Beyer J. Prognostic factors in metastatic germ cell tumour s. Semin Oncol 1998;25:174-85.

170. Motzer RJ, Sheinfeld J, Mazumdar M, et al. Paclitaxel, ifosfamide, and cisplatin second-line therapy for patients with relapsed testicular germ cell cancer. J Clin Oncol 2000;18:2413-8.

171. Loehrer PJ Sr, Gonin R, Nichols CR, et al. Vinblastine plus ifosfamide plus cisplatin as initial salvage therapy in recurrent germ cell tumour . I Clin Oncol 1998; 16:2500-4.

172. Kaye SB, Mead GM, Fossa S, et al. Intensive induction-sequential chemotherapy with BOP/VIP-B compared with treatment with BEP/EP for poor-prognosis metastatic nonseminomatous germ cell tumour : a Randomized Medical Research Council/European Organization for Research and Treatment of Cancer study. J Clin Oncol 1998;16:692-701

173. Kondagunta GV, Bacik J, Donadio A, et al. Combination of paclitaxel, ifosfamide, and cisplatin is an effective second-line therapy for patients with relapsed testicular germ cell tumour s. I Clin Oncol 2005;23:6549-55.

174. Pico IL, Rosti G, Kramar A, et al. A randomised trial of high-dose chemotherapy in the salvage treatment of patients failing first-line platinum chemotherapy for advanced germ cell tumours. Ann Oncol 2005;16:1152-9.

175. Motzer RJ, Cooper K, Geller NL, et al. The role of ifosfamide plus cisplatin-based chemotherapy as salvage therapy for patients with refractory germ cell tumour s. Cancer 1990;66:2476-81.

176. Loehrer PJ Sr, Laver R, Roth BJ, et al. Salvage therapy in recurrent germ cell cancer: ifosfamide and cisplatin plus either vinblastine or etoposide. Ann Intern Med 1988;109:540-6.

177. Droz JP, Ribrag V, Ghosn M, et al. Phase II trial with etoposide (VP16) plus ifosfamide plus high-dose cisplatin (VIhP regimen) in refractory germ cell tumour s. Prog Clin Biol Res 1989;303:739-47.

178. Mardiak J, Salek T, Sycova-Mila Z, et al. Paclitaxel plus ifosfamide and cisplatin in second-line treatment of germ cell tumour s: a phase II study. Neoplasma 2005;52:497-501.

179. Mead GM, Cullen MH, Huddart R, et al. A phase II trial of TIP (paclitaxel, ifosfamide and cisplatin) given as second-line (post-BEP) salvage chemotherapy for patients with metastatic germ cell cancer: a medical research council trial. Br J Cancer 2005;93:178-84.

180. Beyer J, Stenning S, Gerl A, et al. High-dose versus conventional-dose chemotherapy as first-salvage treatment in patients with non-seminomatous germ-cell tumour s: a matched-pair analysis. Ann Oncol 2002; 13:599-605.

181. Motzer RJ, Mazumdar M, Sheinfeld J, et al. Sequential dose-intensive paclitaxel, ifosfamide, carboplatin, and etoposide salvage therapy for germ cell tumour patients. J Clin Oncol 2000; 18:1173-80.

182. Vaena DA, Abonour R, Einhorn LH. Long-term survival after high-dose salvage chemotherapy for germ cell malignancies with adverse prognostic variables. J Clin Oncol 2003;21:4100-4

183. Lorch A, Kollmannsberger C, Hartmann JT, et al. Single versus sequential high-dose chemotherapy in patients with relapsed or refractory germ cell tumour $s$ : a prospective randomized multicenter trial of the German Testicular Cancer Study Group. J Clin Oncol 2007;25:2778-84.

184. Einhorn LH, Williams SD, Chamness A, et al. High-dose chemotherapy and stem-cell rescue for metastatic germ-cell tumour s. N Engl J Med 2007;357:340-8.

185. Kollmannsberger C, Beyer J, Liersch R, et al. Combination chemotherapy with gemcitabine plus oxaliplatin in patients with intensively pretreated or refractory germ cell cancer: a study of the German Testicular Cancer Study Group. J Clin Oncol 2004;22:108-14.

186. Hartmann JT, Schmoll HJ, Kuczyk MA, et al. Postchemotherapy resections of residual masses from metastatic non-seminomatous testicular germ cell tumour s. Ann Oncol 1997;8:531-8.

187. Oldenburg J, Martin JM, Fossa SD. Late relapses of germ cell malignancies: incidence, management and prognosis. J Clin Oncol 2006;24:5503-11.

188. Baniel J, Foster RS, Gonin R, et al. Late relapse of testicular cancer. J Clin Oncol 1995;13:1170-6.

189. Gerl A, Clemm C, Schmeller N, et al. Late relapse of germ cell tumour s after cisplatin-based chemotherapy. Ann Oncol 1997:8:41-7. 
Wood et al.

190. Shahidi M, Norman AR, Dearnaley DP, et al. Late recurrence in 1263 men with testicular germ cell tumour s. Multivariate analysis of risk factors and implications for management. Cancer 2002;95:520-30.

191. Oldenburg J, Alfsen GC, Waehre H, et al. Late recurrences of germ cell malignancies: a populationbased experience over three decades. Br J Cancer 2006;94:820-7.

192. Rutherford EE, Ferguson JL, Geldart TR, et al. Late relapse of metastatic non-seminomatous testicular germ cell tumours. Clin Radiol 2006;61:907-15.

193. Spermon JR, De Geus-Dei LF, Kiemeney LA, et al. The role of (18)ffluoro-2-deoxyglucose positron emission tomography in initial staging and re-staging after chemotherapy for testicular germ cell tumours. BJU Int 2002;89:549-56.
194. Levi JA, Raghavan D, Harvey V, et al. The importance of bleomycin in combination chemotherapy for good-prognosis germ cell carcinoma. Australasian Germ Cell Trial Group. J Clin Oncol 1993;11:1300-5.

195. de Wit R, Sylvester R, Tsitsa C, et al. Tumour marker concentration at the start of chemotherapy is a stronger predictor of treatment failure than marker half-life: a study in patients with disseminated nonseminomatous testicular cancer. Br J Cancer 1997;75:432-5.

Correspondence: Dr. Padraig Warde, Department of Radiation Oncology, 610 University Ave., Toronto, ON M5G 2M9; fax: 416-946-4568; padraig.warde@rmp.uhn.on.ca 